\title{
A Lactobacillus Cocktail Changes Gut Flora and Reduces Cholesterolemia and Weight Gain in Hyperlipidemia Mice
}

\author{
Shousong Yue ${ }^{1 \#}$, Bharathiraja Chinnapandi ${ }^{1 \#}$, Haitao Ge ${ }^{2}$, Xiaofeng Zou ${ }^{1}$, Xiaojing Chen ${ }^{2}$, \\ Chuandong Wang ${ }^{2}$, Wei Hu${ }^{2}$, Jean-François Picimbon ${ }^{1 *}$ \\ ${ }^{1}$ Biotechnology Research Centre, Shandong Academy of Agricultural Sciences, Jinan, P.R. China \\ ${ }^{2}$ State Key Laboratory of Microbial Technology, Shandong University, Jinan, P.R. China \\ "These authors contributed equally
}

Received: May 07, 2014; Accepted: May 31, 2014; Published: June 2, 2014

*Corresponding author: Jean-François Picimbon, Functional Genomics and Proteomics of Chemical Ecology, Microbiology, Plant Transgenesis and Insect Control, Biotechnology Research Center, Shandong Academy of Agricultural Sciences, Jinan, P.R.China, Tel: +86-(531)-83175350; Fax:+86-(531)83178156; E-mail:jfpicimbon@gmail.com

\begin{abstract}
We developed a hyperlipidemia mouse model system to test the effects of natural Lactobacillus bio-products on intestinal microflora, organ physiology and lipid metabolism.

Using denaturing gradient gel electrophoresis, PCR, quantitative real-time PCR and Southern blots, we showed that Lactobacillus had different effects on the intestinal microflora compared to pharmaceutical drugs such as Simvastatin. The pool treated with Lactobacillus (L. plantarum, L. acidophilus and L. casei) was found to be closer than the control conditions. We report the existence of twelve main gut bacterial strains related to lipid metabolism in mice (Bacillus amyloliquefaciens, B. licheniformis, B. oleronius, Enterobacter sp. dc6, Enterococcus faecium, Lactobacillus johnsonii, Lactococcus sp. M3T8B4 and four uncultured bacteria); most of which are found to be regulated by the cocktail of lactobacilli. In addition, results show the reduced levels of cholesterolemia and weight in hyperlipidemia mice as well as beneficial effects on LDL/HDL ratio, neutral lipid accumulation, cholesterol removal and antioxidant activities following treatments with Lactobacillus.
\end{abstract}

On the basis of these results we propose the use of $L$. plantarum, $L$. acidophilus and $L$. casei in a new bio-product cocktail not only as a food complement to regulate the gut flora and prevent lipid accumulation but also as an alternate therapy to pharmaceutical drugs for the treatment of hyperlipidemia, obesity and all other genetic disorders that cause severe deficiency in lipid metabolic pathways.

Keywords: Bioproduct; L. plantarum; L. acidophilus; L. casei; Simvastatin; Ubac2; HDL; LDL; Lipid metabolism

\section{Abbreviations}

AI: Atherosclerotic Index; Blic: Bacillus licheniformis; Bm9h: Bacillus M9H; Bole: Bacillus oleronius; Bamy: Bacillus amyloliquefaciens; CH: Cholesterol; DGGE: Denatured Gradient Gel Electrophoresis; DPPH: Di-Phenyl-Picryl-Hydrazyl; Edc6: Enterococcus dc6; Efae: Enterococcus faecium; HDL: High Density LipoProtein; LDL: Low Density Lipoprotein; M3T8: Lactococcus M3T8B4; Ljoh:
Lactobacillus johnsonii; NBT/BCIP: Nitro-Blue-Tetrazolium,5Bromo-4-Chloro-3'-IndolyPhosphate; RT-PCR: real time PCR; SAFR: Superoxide Anion Free Radicals; TG: Triglycerides; Ubac1: Uncultured bacterium 1; Ubac2: Uncultured bacterium 2; Ubac3: Uncultured bacterium 3; Ubac4: Uncultured bacterium 4

\section{Introduction}

Hyperlipidemia is associated to obesity, which is a major worldwide health concern even though considering it as a disease can be a matter of debate [1]. Being overweight due to the accumulation of excess body fat has become epidemic and concern individuals of all ages, including not only adults but also children from many countries all over the world [2-4]. Understanding of lipid metabolism, hyperlipidemia, weight gain, diabetes, cancers and all forms of obesity remains complex [5]. Lipid accumulation impacts a lot of endocrine and metabolic systems from heart to ovaries, leading potentially to cardiovascular accidents and/ or cancer [6]. One of the most urgent challenges for human health protection is therefore to develop strategies to tackle hyperlipidemia before it generates disability or fatal issue.

In view of this challenge, it is important to note that in animal models obesity can be strongly associated with changes in the composition of the gut bacterial microflora [7]. In mice, high-fat-diet intake is shown to induce severe changes in the gut bacterial microflora only in a few days time. Normal mice inoculated with the microflora of obese mice become readily fatter than those inoculated with the microflora of leaner mice [8]. Reversely, normal mice that received gut bacteria from mice that lost weight following gastric bypass surgery also lost weight $[9,10]$. Important host physiological systems such as the immune response and lipid metabolism are tightly connected with the gut bacterial microflora [11]. Beneficial bacteria in the gut are known to stimulate the lymphoid tissue to produce antibodies directed against specific pathogens or to prevent the development of harmful microbes directly through the "barrier effect" at the intestinal mucosa level [12]. Unbalanced gut flora can lead to 
disease through generation of pro-atherosclerotic phospholipid metabolites [13]. Lactobacilli or any other gut microbial flora are well reported to keep the lipid metabolism in vascular biology, as filed for the lipid composition, LDL/HDL ratio, atherosclerotic index and neutral lipid accumulation. These results suggest that appropriate medicine chemicals or bacterial probiotics should be used for treatment of obesity and overweight to restore first a positive microflora in order to prevent the development of immune and/or cardiovascular diseases [14].

Although some gut bacterial phylotypes remain to be identified, the composition of the gut microbiota is known in both human and animal models as Actinobacteria, bacteroidetes, Firmicutes, Proteobacteria and in less extent Fusobacteria and Verrucomicrobia [15]. The current view in animal models is that hyperlipidemia is linked to unbalanced proportions between such bacterial phylotypes; high cholesterolemia would be mainly associated with high levels of Bacteroidetes and low levels of Firmicutes $[16,17]$. Dietary supplements containing probiotics of the Firmicutes group such as Lactobacillus spp., Bifidobacterium spp., and Enterococcus spp., are frequently used to maintain the health and weight of livestock accordingly [18]. Increasing Lactobacillus strain-levels in the gut flora of newborn chicks and ducks is associated with weight gain [19]. However, in humans, the relationship between body lipid levels, gut microflora and Lactobacillus is not so clear [20-23]. In contrast, abundance of Fusobacterium and Tenacibaculum has been reported in older subjects of the Amish population where it could be responsible for colon cancer [24].

Humankind has been consuming probiotics throughout most of its history without inducing apparent hyperlipidemia or obesity in healthy adults $[25,26]$. However, a number of studies have reported weight gain in children given Lactobacillus spp. as a treatment for diarrhea, suggesting that perhaps probiotics could be related to hyperlipidemia and/or have various agedependent effects $[27,28]$.

Here, we present strong support that using a specific Lactobacillus bio-product cocktail (L. plantarum, L. acidophilus and L. casei) has performed as equal to or better than Simvastatin on both blood lipid concentration and fat body distribution during treatments of hyperlipidemia. Lactobacillus is shown not only to prevent lipid accumulation during fat diet intake but also to help maintain a normal gut microflora. Such a finding might be very important to help develop a "natural" therapy against the hyperlipidemic conditions, gain weight, obesity and related metabolic diseases.

We initiated a four-points study to characterize key bacterial phylotypes associated with hyperlipidemia, weight gain and chemical versus bacterial treatment: 1) develop a mouse model of hyperlipidemia, 2) identify bacterial strains specific to the hyperlipidemic status (overweight and high blood lipid concentration), 3) test the effects of Lactobacillus and 4) compare with the effects of the pharmaceutical agent Simvastatin. Our combined culture and molecular analysis allowed identification of twelve dominant strains in the mouse fecal and gut samples. Then, using DGGE and qPCR, we showed that except $B$. licheniformis, strain-levels for all identified bacteria such as BM9H, B. oleronius, B. amyloliquefaciens, Enterobacter sp. dc6, E. faecium, L. johnsonii, M3T8B4, Ubac1, UBac2, Ubac3 and Ubac4 were significantly affected by hyperlipidemia. Most importantly, bacterial strains such as Ubac4 were significantly up-regulated in ill hyperlipidemic mice but significantly down-regulated in model mice treated with Lactobacillus. In addition, measuring various physiological and metabolic parameters in the different groups of mice, we showed that the pools of mice treated with Lactobacillus not only had a gut flora closer to control conditions but clearly lost weight and had seriously improved lipidemia and cholesterolemia. Finally, we showed that each specific Lactobacillus single-strain of the bacterial blend had very potent antioxidant activities.

\section{Materials and Methods \\ Bio-product composition}

In a preliminary study, we tested the effects of single-strain Lactobacillus probiotics on improvement of hyperlipimedia (cholesterol-lowering). We found that single-strain Lactobacillus bio-products had no significant effects on cholesterol-lowering and blood lipid concentration (Table 1).

The probiotics used in this study on hyperlipidemia were a cocktail of three specific strains of Lactobacillus (Lactobacillus plantarum SD02, L. acidophilus SD65 and L. casei SD07) traditionally maintained in our laboratory. Growth of pure cultures of the three bacterial strains was taken in MRS liquid medium placed in an anaerobic workstation held permanently at $37^{\circ} \mathrm{C}$ (industrial platform). For bioproduct sample preparation, bacterial cells of each strain were centrifuged at $2000 \times \mathrm{g}$ for 20 $\min$ at $4^{\circ} \mathrm{C}$. The bacterial cell pellets were resuspended in the ratio of $10^{9} \mathrm{CFU} / \mathrm{ml}$ in sterile saline water and stored at $4^{\circ} \mathrm{C}$ until use. Probiotic solutions were freshly prepared by mixing the three bacterial suspensions in an equal volume just before treatment. Mice received every day $0.3 \mathrm{ml}$ of bioproducts administered intra-gastrically using a stainless-steel needle.

\section{Experimental mice model}

The use of live mice in this study was approved by the Shandong University Animal Research Ethics Committee and was licensed by Shandong Province (governmental license SCXK Lu 20090001).

The experimental design is represented on Figure 1. Seventyseven weeks-old healthy male white mice (purchased from Laboratory Animal Center, Shandong University, Jinan, China) with a body weight of 20-22 grams were used for experimental studies. Mice were housed separated in three different groups maintained at $20 \pm 2{ }^{\circ} \mathrm{C}$ and $50 \pm 5 \%$ humidity in a sterile or free pathogen environment (ethical clearance). In step 1 (development of hyperlipidemic model ill-mice), mice from Group 1 were fed during twenty days with standard diet (wt/wt) composed of barley meal $20 \%$, dehydrated cabbage $10 \%$, soybean meal $20 \%$, dry yeast $1 \%$, bone powder $5 \%$, corn meal $16 \%$, fish meal $10 \%$ and salt $2 \%$ (control-conditions), while mice from Group 2 were fed with the same diet complemented with high fat. High lipid 
Table 1: Effects of Lactobacillus single-strains on cholesterol-lowering and lipid metabolism

\begin{tabular}{|c|c|c|c|c|c|}
\hline & Mice & $\begin{array}{c}\text { Cholesterol } \\
\text { (mmol/L) }\end{array}$ & $\begin{array}{c}\text { Triglycrides } \\
\text { (mmol/L) }\end{array}$ & $\begin{array}{c}\text { LDL } \\
(\mathrm{mmol} / \mathrm{L})\end{array}$ & $\begin{array}{c}\text { HDL } \\
(\mathrm{mmol} / \mathrm{L})\end{array}$ \\
\hline \multirow{5}{*}{ Step1 } & High-fat diet & $4.22 \pm 0.37 \mathrm{a}$ & $1.09 \pm 0.18 \mathrm{a}$ & $2.24 \pm 0.14 \mathrm{a}$ & $0.94 \pm 0.05 a$ \\
\hline & L. plantarum & $3.74 \pm 0.47 a$ & $1.00 \pm 0.19 a$ & $1.92 \pm 0.23 a$ & $0.84 \pm 0.11 \mathrm{a}$ \\
\hline & L. casei & $3.84 \pm 0.37 a$ & $0.77 \pm 0.17 \mathrm{a}$ & $2.46 \pm 0.14 \mathrm{a}$ & $0.86 \pm 0.11 \mathrm{a}$ \\
\hline & L. acidophilus & $3.99 \pm 0.37 a$ & $1.12 \pm 0.29 a$ & $2.3 \pm 0.14 \mathrm{a}$ & $1.08 \pm 0.10 \mathrm{a}$ \\
\hline & Mice & $\begin{array}{c}\text { Cholesterol } \\
\text { (mmol/L) }\end{array}$ & $\begin{array}{c}\text { Triglycrides } \\
\text { (mmol/L) }\end{array}$ & $\begin{array}{c}\text { LDL } \\
(\mathrm{mmol} / \mathrm{L})\end{array}$ & $\begin{array}{c}\text { HDL } \\
(\mathrm{mmol} / \mathrm{L})\end{array}$ \\
\hline \multirow{4}{*}{ Step2 } & $\begin{array}{c}\text { Medicine } \\
\text { (Simvastatin) }\end{array}$ & $4.06 \pm 0.59 a$ & $0.89 \pm 0.11 \mathrm{a}$ & $2.46 \pm 0.2 \mathrm{a}$ & $0.93 \pm 0.11 \mathrm{a}$ \\
\hline & L. plantarum & $4.07 \pm 0.45 a$ & $1.00 \pm 0.24 \mathrm{a}$ & $2.34 \pm 0.15 a$ & $0.80 \pm 0.16 a$ \\
\hline & L. casei & $4.33 \pm 0.34 \mathrm{a}$ & $0.92 \pm 0.16 \mathrm{a}$ & $2.38 \pm 0.076 a$ & $0.88 \pm 0.13 a$ \\
\hline & L. acidophilus & $4.24 \pm 0.35 a$ & $0.82 \pm 0.09 a$ & $2.29 \pm 0.17 \mathrm{a}$ & $0.87 \pm 0.02 \mathrm{a}$ \\
\hline
\end{tabular}

Values represent mean \pm SEM. Values followed by the same letter do not differ significantly.

(4)

\section{(2)}
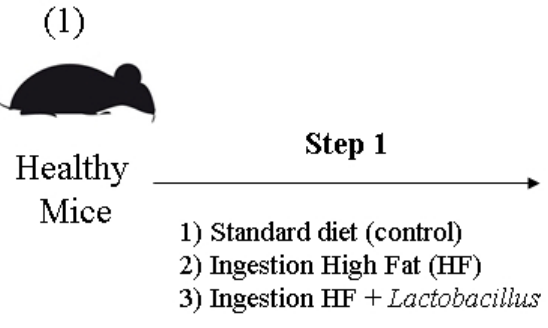

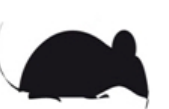

Model

Mice

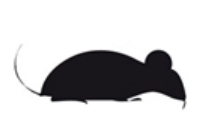

(3)

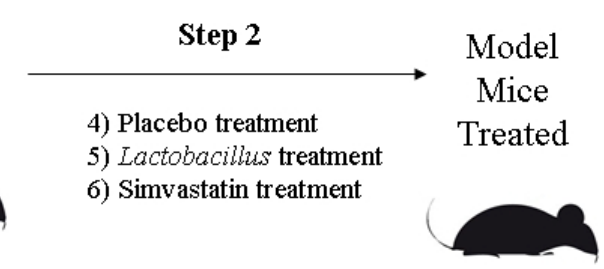

(5) \& (6)

Figure 1: Hyperlipidemia mice models. Step 1 (feeding phase): 1) Standard diet (control), 2) Ingestion high fat (HF), 3) Ingestion HF plus Lactobacillus; Step 2 (treatment phase): 4) Fat mice (ill-conditions) treated with placebo, 5) Fat mice treated with Lactobacillus cocktail, 6) Fat mice treated with Simvastatin.

diet was composed of standard diet (80\%,wt/wt) plus lard $5 \%$, egg $5 \%$ and whole milk powder $10 \%$. Mice from Group 3 were fed with high fat diet complemented with lactobacillus bio-product. Bio-product was administered by a daily injection of $0.3 \mathrm{ml}(10$ $\mathrm{ml} / \mathrm{kg}$ of bodyweight). Groups 1 and 2 received a daily injection of $0.3 \mathrm{ml}$ of saline water.

In step 2 (treatment of hyperlipidemic model mice), doubleweighted mice (40-44 grams) were divided into three additional groups and reared as described before for fourteen days. During this period, fat mice were fed with standard diet throughout the whole experiment and had free access to water and food. Fat mice from group 4 (ill-conditions) were injected daily with 0.3 $\mathrm{ml}$ of placebo (saline water), while fat mice from groups 5 and 6 were injected daily with $0.3 \mathrm{ml}$ of probiotics $(10 \mathrm{ml} / \mathrm{kg}$ of body weight) and simvastatin solution $(3.0 \mathrm{mg} / \mathrm{kg}$ of body weight), respectively, following SFDA instructions.

Body weight and feed intakes of fat mice were recorded every $24 \mathrm{~h}$ starting from the beginning of step 1 . At the same time, mouse fecal droppings were collected in sterile Eppendorf tubes and immediately stored at $-70^{\circ} \mathrm{C}$ until further experiments.

\section{Identification of bacterial DNA profiling}

For Denaturing Gradient Gel Electrophoresis (DGGE) fingerprinting analysis, PCR and real-time PCR, microbial genomic DNA was extracted from fecal pellets in the six groups of mice using the phenol chloroform/isoamyl alcohol/ethanol extraction method. Fecal pellets were first freeze-dried and homogenized in $500 \mu \mathrm{l}$ of extraction buffer (Tris-EDTA/NaCl pH $8.0,20 \mathrm{mg} / \mathrm{ml}$ proteinase $\mathrm{K}, 20 \% \mathrm{wt} / \mathrm{vol}$ SDS) before incubation for $1 \mathrm{~h}$ at $37^{\circ} \mathrm{C}$. Genomic DNA from the gut of control and Lactobacillus-treated mice of step 2 were prepared following the same procedure. Extracted genomic DNA from feces and gut was dissolved in sterile milli- $\mathrm{Q}$ water for a final concentration of about $1 \mu \mathrm{g} / \mu \mathrm{l}$ and stored at $-20^{\circ} \mathrm{C}$. until further use in molecular biology experiments (PCR, real-time PCR and Southern blots).

Prelude to DGGE, an amount of ten to twenty nanograms of total genomic DNA was used as a template for the PCR amplification of V3 region of $16 \mathrm{~S}$ rDNA (ribosomal DNA) using conserved universal bacterial primers: $16 \mathrm{~F}$ 5'-CGC CCG GGG CGC GCC CCG GGCGGG GCG GGG GCA CGG GGG G AGA GTT TGA TCM TGG CTC AG-3' and 16R 5'-TAC GGY TAC CTT GTT ACG ACT T-3' (Invitrogen, Shanghai, China). Such universal primers 
were mandatory to obtain the fingerprints of the main bacterial community present in the different fecal samples [29]. PCR amplification of $16 \mathrm{~S}$ rDNA products (TransGen Biotech, Beijing, China) was carried out in a Takara Master Thermal Cycler Dice (Takara, Dalian, China) programmed for an initial denaturation of $95^{\circ} \mathrm{C}$ for $3 \mathrm{~min}$ followed by 30 cycles of $\left(94^{\circ} \mathrm{C}\right.$ for $\left.30 \mathrm{~s}\right), 50^{\circ} \mathrm{C}$ for $30 \mathrm{~s}, 72^{\circ} \mathrm{C}$ for $1 \mathrm{~min}$ and a final extension of $72^{\circ} \mathrm{C}$ for $7 \mathrm{~min}$. The $16 \mathrm{~S}$ rDNA PCR products were then used to compare the bacterial profiles between the six samples of mouse feces.

Mixtures of PCR-derived 16S rDNA products were separated on a $6 \%(\mathrm{wt} / \mathrm{vol})$ polyacrylamide gel with a denaturant gradient ranging from 40 to $65 \%$ optimized for $\mathrm{V} 3$ region. Electrophoresis was run for $7 \mathrm{~h}$ in TAE $1 \mathrm{x}$ running buffer at constant voltage $(100 \mathrm{~V})$ with a temperature of $60^{\circ} \mathrm{C}$ in a Junyi JY-TD331-DGGE system (Dong Fang Electrophoresis Equipment Co. LTD, Beijing, China). After electrophoresis, gels were stained for 15 min with ethidium bromide and visualized under UV light. The final result of DGGE images was analyzed using Quantity One® (1-D analysis software, Version 4.4.0, Bio-Rad, Hercules, California, USA).

\section{Isolation and Identification of fecal bacteria}

To identify most dominant bacteria in feces from mice in the six different groups, fecal samples from Group 1-6 mice were processed for bacterial cultures on LB medium using most conventional methods. About twenty colonies in each series of samples were selected for genomic DNA, extraction, PCR, cloning and sequencing. Total genomic DNA was extracted from pure cultured strains as described before and used as template (10 ng) in PCR reactions employing 16F and 16S universal primers (Invitrogen, Shanghai, China; see before). Strain-specific 16S rDNA PCR products were purified using Qiaquick Gel Extraction Kit (Qiagen, Valencia, California, USA) and cloned into pMD-19-T simple vector (Takara Biotechnology, Dalian, China). 16S rDNA clones specific for single strains were sequenced on ABI-PRISM 3730 automated sequencing system using $16 \mathrm{~S}$ or $16 \mathrm{R}$ primer, Big Dye Ready Reaction DyeDeoxy Terminator Cycle Sequencing kit and Applied Biosystems AmpliTaq DNA Polymerase (PerkinElmer, Weiterstadt, Germany). Sequences obtained were assembled using AutoAssembler (PE-Applied Biosystems, Foster City, California, USA) and subjected to BLAST analysis using the server at NCBI, identifying new strains or strains with $99 \%$ identity to some known bacterial species (Acc. Nb. KC347584, KC347585, KC347586, KC347587, KC347588, KC347589, KC347590, KC347591, KC441061, KC441062, KC441063, KC441064).

Universal $16 \mathrm{~S}$ and $16 \mathrm{R}$ primers were then used to amplify genomic DNA of strain-specific cultures and map Lactobacillus johnsonii, Lactococcus sp. M3T8B4, Enterococcus faecium, Enterobacter sp. dc6, Bacillus licheniformis, Bacillus oleronius, Bacillus amyloliquefaciens, Bacillus BM9H, Ubac1, Ubac2, Ubac3 and Ubac4 on the DGGE profile (Table 2). Metagenomic DNA was isolated from both mouse feces and bacterial cultures as described before. The same procedure was used for DGGE (see under Identification of bacterial DNA profiling). The two PCRDGGE profiles were compared on the same $6 \%$ polyacrylamide gel, identifying Efae, Ubac3 and Ubac4 as main bacteria in the mouse fecal samples of step 2 .

\section{Probe synthesis and Southern blotting analysis}

PCR-amplified 16S-rDNA products were used as templates for preparation of probes for Southern blots. Fecal microbial 16S rDNA (QIAamp DNA stool kit, Qiagen, USA) were amplified using 16S primers in PCR $\left(95^{\circ} \mathrm{C} 3 \mathrm{~min}, 30\right.$ cycles: $94^{\circ} \mathrm{C} 30 \mathrm{~s}, 50^{\circ} \mathrm{C} 30$ $\mathrm{s}, 72^{\circ} \mathrm{C} 1 \mathrm{~min}, 72^{\circ} \mathrm{C} 7 \mathrm{~min}$ ). The $16 \mathrm{~S}$ rDNA PCR products were then purified and labeled with DIG-dUTP (alkali labile) using 1 $\mu \mathrm{g}$ of denatured DNA (DIG-High prime labeling kit, Roche Applied Science, Mannheim, Germany). Prelude to Southern blot, gut microbial 16S-rDNA products $(1 \mu \mathrm{g})$ were amplified in PCR in similar conditions using Ubac2 strain-specific primers (Table 2). Strain-specific rDNA PCR products were then separated using agarose gel electrophoresis and blotted onto Hybond nylon membrane (GE Healthcare, Pittsburgh, Pennsylvania, USA) by capillary transfer in 20x SSC buffer for $12 \mathrm{~h}$ at $37^{\circ} \mathrm{C}$. Membranes were then dried for $2 \mathrm{~h}$ at $80^{\circ} \mathrm{C}$ and pre-hybridized in $20 \mathrm{ml}$ of 1x hybridization buffer (DIG Easy Hyb Roche Applied System, Mannheim, Germany) for $2 \mathrm{~h}$ at $42^{\circ} \mathrm{C}$ in a vacuum hybridization oven (model HB-1D, Techne ${ }^{\circledR}$, Princeton, New Jersey, USA). Hybridization was performed by incubating the membrane for $12 \mathrm{~h}$ at $42^{\circ} \mathrm{C} 10 \mathrm{ml}$ of $1 \mathrm{x}$ hybridization buffer containing a $\mathrm{Ubac} 2$ specific DIG-labeled DNA probe at a concentration of $25 \mathrm{ng} /$ $\mathrm{ml}$. After hybridization, membranes were washed at $25^{\circ} \mathrm{C}$ with SSC/SDS then blocked to prevent any non-specific binding of the antibody (1:10 000 dilution). Finally, hybridization signals were revealed using nitroblue tetrazolium salt/bromo-chloro-indolylphosphate (NBT/BCIP, DIG-High prime labeling kit, Roche Applied Science, Mannheim, Germany).

\section{qPCR}

Precise quantification (Ct) of the twelve main bacterial strains identified in mouse fecal and gut samples was performed by real-time PCR using the MyiQTM Single-Color Real-Time PCR Detection System on optical grade 96-well plates (Bio-Rad, Hercules, USA). Real-time PCR reactions $(20 \mu \mathrm{l})$ were carried out in triplicates on three different samples $(n=9)$. Bacterial strain levels were measured by using the Fast Start Essential DNA Green Master Kit (Roche), with $0.5 \mu \mathrm{mol}$ of each forward and reverse primer (Invitrogen, Shanghai, China) and $10 \mathrm{ng}$ of genomic DNA templates. Primers were those from Table 2. The real-time PCR program was optimized for fecal and gut DNA: $95^{\circ} \mathrm{C}$ for $600 \mathrm{~s}$ and 45 cycles of $95^{\circ} \mathrm{C}$ for $20 \mathrm{~s}, 55^{\circ} \mathrm{C}$ for $20 \mathrm{~s}$ and $75^{\circ} \mathrm{C}$ for $15 \mathrm{~s}$. After amplification, melting curve analysis was performed by slow heating from $65^{\circ} \mathrm{C}$ to $95^{\circ} \mathrm{C}\left(1^{\circ} \mathrm{C}\right.$ per cycle for $10 \mathrm{sec}$ ) with fluorescence acquisition using $0.1^{\circ} \mathrm{C}$ intervals. The threshold cycle $(\mathrm{Ct})$ values and baseline settings were recorded using the software implemented in MYiQ to allow calculation of the prevalence levels for each test bacterial strain on the basis of the equation $2^{\wedge}$ (-deltadeltaCt) [30]. Blic-levels were used as internal reference. Bacterial strains of feces from mice under control conditions and gut of ill mice were used as reference series, respectively (control levels $=1$ ). Statistical analysis of qPCR data was performed using SPSS Statistics 22. 
Table 2: Primers for quantification of twelve main bacterial strain levels in mouse gut and feces.

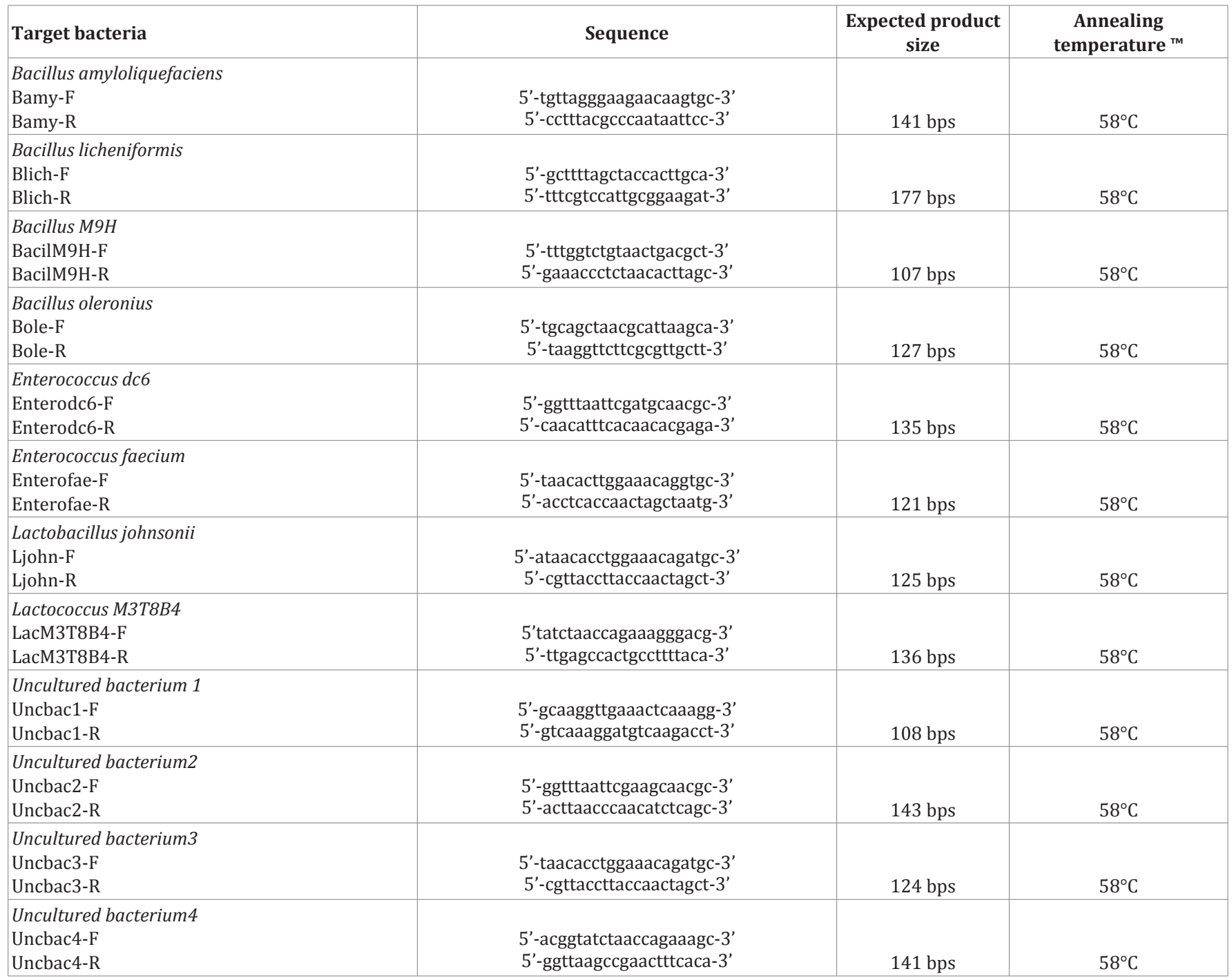

Table 3: Similarity matrix of the fecal bacterial profiling from mice subjected to illness and treatment conditions.

\begin{tabular}{|c|c|c|c|c|c|}
\hline Mice & (1) & (2) & (3) & (4) & \\
\hline$(1)$ & 100 & & & \\
\hline$(2)$ & 72.8 & 100 & 100 & & \\
\hline$(3)$ & 68.9 & 71.3 & 68.9 & 100 & \\
\hline$(4)$ & 67.9 & 65.9 & 54.7 & 53.5 & \\
\hline$(5)$ & 62.3 & 61.9 & 33.9 & 35.7 & \\
\hline$(6)$ & 29.8 & 35.7 & & \\
\hline
\end{tabular}

(1): Standard diet, (2): High-Fat diet, (3): High-Fat diet and Lactobacillus complement (Step 1), (4): Ill mice, (5): Ill mice treated with Lactobacillus, (6): Ill mice treated with Simvastatin (Step 2).

\section{Gut collection and tissue measurements}

At the end of step 1 (groups 1-3) and step 2 (groups 4-6), mice were fasted for $12 \mathrm{~h}$ and euthanized. In each group of mice, visceral organs such as kidney, gut, liver, spleen, pancreas and the subcutaneous intra-abdominal adipose tissues (perirenal and epididymal fat pads) were then collected aseptically under a laminar airflow hood and weighted using a Sartorius BP211D
(Sartorius, Göttingen, Germany). The gut was kept for DNA extraction and identification of strain-specific levels following treatments in step 2: 1) Control, 2) Lactobacillus treated mice.

\section{Measurement of blood cholesterol and lipids}

Blood samples were collected from the eye socket and kept at $0^{\circ} \mathrm{C}$ for 30 minutes before centrifugation at $2000 \times \mathrm{g}$ for 15 minutes at $4^{\circ} \mathrm{C}$ to separate blood components. The cell pellets 
were discarded, while the serum samples were stored at $-70^{\circ} \mathrm{C}$ until measurement of lipidemia. Serum total cholesterol (TC), triglycerides (TG), high-density lipoprotein (HDL) and lowdensity lipoprotein (LDL) were determined using commercial kits (Changchun Huili Bio-chemical Co., Ltd). Atherosclerotic index (AI) was calculated by using the equation TC-HDL/HDL.

Data were analyzed using SPSS Statistical software. Data were tested by analysis of variance (ANOVA). Means were compared across groups by Ducan tests, significance being declared when $p \leq 0.05$ or $p \leq 0.01$.

\section{Determination of scavenging abilities of Lactobacillus strains}

The three strains of Lactobacillus (L. plantarum SD02, $L$. acidophilus SD65 and L. casei SD07) were prepared as described under "Bio-product composition". Determination of cholesterol removal rate was according to Brashears et al. [31]. Assessment of the scavenging capacity of the DPPH radical by various Lactobacillus strains was carried out according to the procedure described by Wang et al. [32]. Assay of scavenging capacity against the superoxide anion free radicals (SAFRs) was according to Sah et al. [33].

\section{Results and Discussion}

A mouse model of hyperlipidemia was developed to identify specific bacteria associated with lipid metabolism and test the effects of a new cocktail of Lactobacilli bio-products versus Simvastatin on variation in composition of the intestinal gut flora as well as on prevention and treatment of cholesterolemia and weight gain (Figure 1).

Using universal primers in DGGE experiments amplified various DNA bands, each representing a specific bacterial strain (Figure 2). Interestingly, comparing DGGE profiles of the fecal microbial community in the different groups of mice from Step 1 and 2 showed clear differences between mice fed with fat diet and those fed with fat diet and Lactobacillus and between all three groups in Step 2 (Figure 2A). Most notably, the bacterial community diversity revealed by the DGGE fingerprinting showed that specific bacterial strains were induced after high-fat diet intake and/or treatment with Lactobacillus or Simvastatin (Figure 2B). Sequencing bacterial cultures from mouse fecal samples identified four "uncultured" bacteria (Ubac1, Ubac2, Ubac3 and Ubac4), Lactobacillus johnsonii, Lactococcus sp. M3T8B4, Enterococcus faecium, Enterobacter sp. dc6, Bacillus amyloliquefaciens, B. licheniformis, B. oleronius and B. $M 9 H$. Trillions of bacteria probably exist in the mouse flora playing a key role in the regulation of the digestive tract and thereby many other physiological systems such as development, brain function and modulation of the immune system [34-37]. However, these particular twelve strains are found to be an essential part of the mouse fecal and gut microbial catalogue (Table 2). Using universal primers to amplify DNA in fecal samples and such twelve bacterial cultures showed similar DNA band profiles between fecal samples of ill mice and bacterial strains such as E. faecium, Ubac3 and Ubac4. Comparing DNA bands from DGGE mapping also showed strong similarities between fecal samples of mice treated with Simvastatin and two main bacterial strains, $B M 9 H$ and Ubac1 (Figure 2C).

Whether these bacterial strains interfere with the mouse gut flora and its metabolic functions in a beneficial manner needs to be studied with caution. Many Bacillus bacteria such as B. anthracis, $B$. cereus and B. subtilis are known to produce toxins that affect human health through damage on both digestive and immune systems [38-41]. Enteroccoci are well known highly resistant human pathogens that can spread over the whole body and cause various diseases from meningitis and bacteremia to endocarditis, diverticulitis and urinary infections [42-44]. Ubac1 (KC347585) is significantly related to E. faecium strain S4 (KC478508). If this new Enteroccocus strain induced by Simvastatin has harmful secondary effects similar to those from Bacillus and Enteroccocus bacteria, a new remedy alternative to Simvastatin needs urgently to be used to cure hyperlipidemia. In our study, using drug therapy (Simvastatin) is found to affect the gut microflora much more than a Lactobacillus therapy (Figures 2 \& 3, Table 3). Many potentially toxic bacterial strains are up-regulated by Simvastatin (Figure 2). In contrast, levels of potentially beneficial bacteria such as Ubac2 are reduced by Simvastatin treatment (Figure 3). The similarity matrix shows index value pairs of 22.1-35.7 for the gut flora of mice treated with Simvastatin compared to other treatments, while index value pairs of 53.5-62.3 are found for the gut flora of mice treated with Lactobacillus (Table 3).

Simvastatin is known for a lot of side effects such as diarrhea, swelling, weight gain, increased thirst, nausea, abdominal pain, a loss of appetite, constipation and water retention. Persistent liver and gastro-intestinal disorders up to diabetic problems are observed in patients on Simvastatin or any other statin drug (MRC/BHF Heart Protection Study Collaborative Group, 2009) [45]. Our results show that one major cause for the secondary effects of the chronic usage of Simvastatin is most probably to be an altered gut flora. Many antibiotic chemicals used in medicine and animal rearing are well known to be efficient to treat pathogenic bacterial strain-levels but also to have long-term effects on the composition of the normal gut flora thus predisposing the body to develop new illness $[46,47]$. Strains of bacterial pathogens may become dominant due to loss of bacterial diversity in the gut following specific antibiotic chemical treatments [48]. Meanwhile, use of antibiotics and chemical treatments are clearly prohibited for pregnant women. The probability for the child to develop diseases such as asthma is rather high if the mother takes antibiotics [49]. More natural treatments or specific co-treatment with bioproducts are necessary to cure bacterial infections while maintaining normal strain-levels in the gut flora.

Levels of abundance have been determined precisely using qRT-PCR for the twelve bacterial strains in all six groups of mice (Table 4 \& Figure 4). Internal reference was Blic-levels for which no statistically significant differences were found between mean Ct values of different treatments (Table 4). Results show that Lactobacillus, Lactococcus, Enterococcus and other uncultured bacterial species from the genus Enterococcus are significantly down-regulated by fat diet intake (Figure 4). We show the occurrence of specific bacterial strains that are significantly 
A.
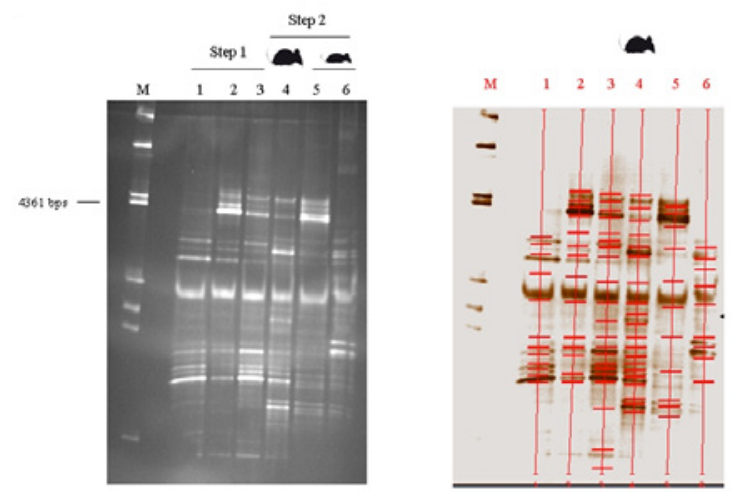

в.
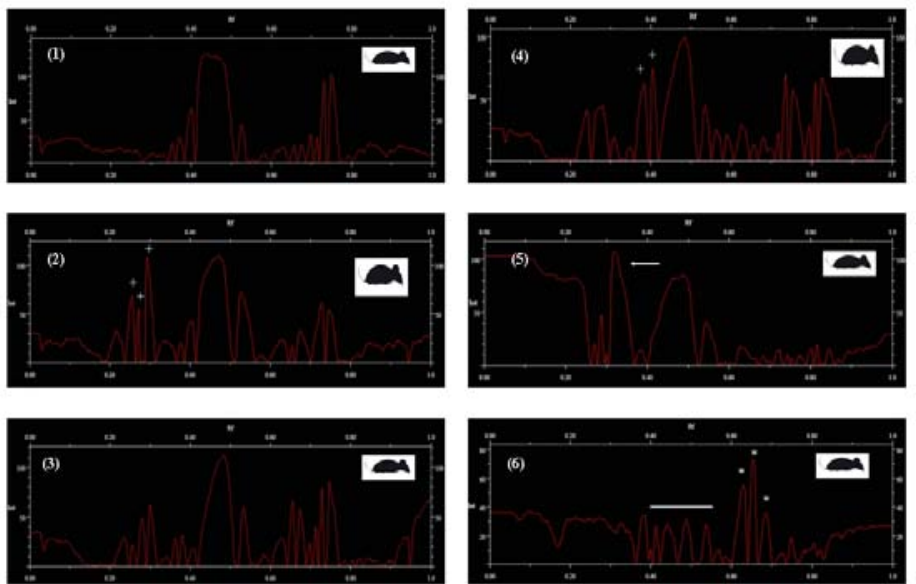

Step 1

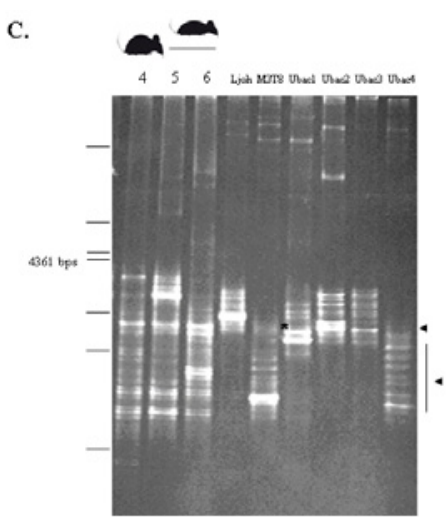

Step 2

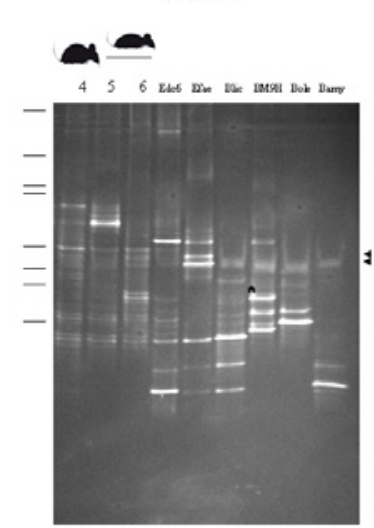

Figure 2: High-fat diet intake-, Lactobacillus- and Simvastatin-associated changes in the mouse fecal microbial flora. A: DGGE profiles (left) and One Quantity analysis (right) of the fecal microbial flora in mice after high-fat diet intake (step 1) and post-treatment phase (step 2). A right: 1: Standard diet, 2: Fat diet, 3: Fat diet and Lactobacillus complement, 4: Ill mice, 5: Ill mice treated with Lactobacillus, 6: Ill mice treated with Simvastatin. The DGGE profiles are constructed using universal primers tuned to the conserved V3 region of bacterial genomes. The DGGE profile of feces from ill mice (lane 4) is characterized by a high density of bacterial bands. The bacterial DGGE profiles completely differ between ill mice treated with Lactobacillus (lane 5) and those treated with Simvastatin (lane 6). M: Molecular weight markers (Lambda DNA/Hind III Plus Markers: 3130, 9416, 6557, 4361, $2322,2027,564,125)$. B: Analysis results of lane comparison from the DGGE profiles using Quantity One 4.4 .0 software. Significant differences are found between the bacterial profiles of mice from groups 1 to 6. " + " shows specific bacterial-strain levels increased after intake of high-fat diet in absence of Lactobacillus during step 1 (2) and in ill mice of step 2 (4). The arrow shows a peak of bacteria in ill mice treated with Lactobacillus (5). The dash shows bacterial strain-levels decreased in ill mice after Simvastatin treatment in step 2 (6). The asterisks show specific bacterial-strain levels increased after Simvastatin treatment (6). C: DGGE mapping of bacterial strains identified in mouse fecal samples. DGGE profiles of Ljoh, L8b4, Ubac1, Ubac2, Ubac3 and Ubac4 (left) and Edc6, Efae, Blic, Bm9h, Bole, Bamy, M3T8 (right) compared to fecal DNAs from mice of step 2 amplified with universal primers. Markers (Lambda DNA/Hind III Plus) are shown on the left of the gel. * indicates specific DNA bands for Bacillus M9H and uncultured bacterium 1 (Ubac1). Arrowheads indicate diagnostic bands for Efae, Ubac3 and Ubac4. Blic: Bacillus licheniformis, Bamy: Bacillus amyloliquefaciens, Bole: Bacillus oleronius, Bm9h: Bacillus M9H, Edc6: Enterococcus dc6, Efae: Enterococcus faecium, Ljoh: Lactobacillus johnsonii, M3T8: Lactococcus M3T8B4, Ubac1: Uncultured bacterium 1, Ubac2: Uncultured bacterium 2, Ubac3: Uncultured bacterium 3, Ubac4: Uncultured bacterium 4. 


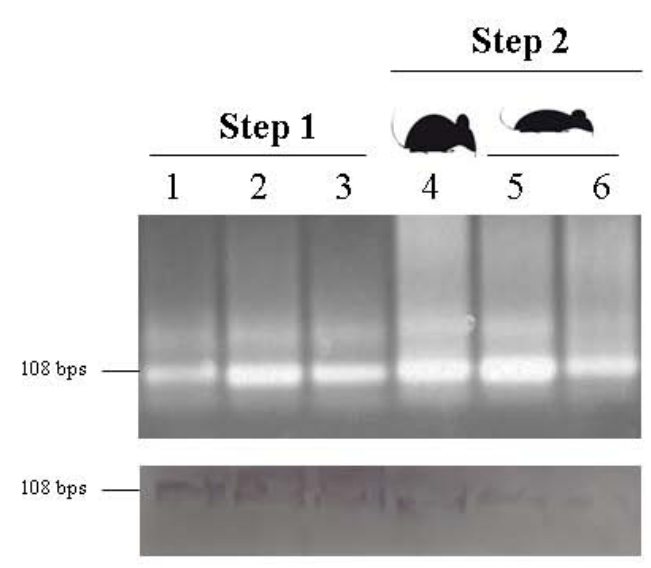

Ubac2

Figure 3: Regulation of bacterial strain-levels by Lactobacillus and Simvastatin. Southern blots of 16S rDNA products from gut genomic DNA of mice from the groups 1 to 6. 1: Mice subjected to standard diet, 2: Mice subjected to high-fat diet, 3: Mice subjected to high-fat diet complemented with Lactobacillus, 4: Ill mice treated with placebo, 5: Ill mice treated with Lactobacillus, 6: Ill mice treated with Simvastatin. Using Ubac2 strain-specific DNA probe shows significantly decreased bacterial strain-levels following Simvastatin treatment (see lane 6).

decreased or increased after high fat diet in our mouse model of hyperlipidemia. E. faecium and Ubac4 bacterial strain-levels are found to be abnormally high (tenfold increased) in fecal samples of ill-mice that have been subjected to heavy fat diet intake (Step 2; Figure 4A). In ill mice, levels of L. johnsonii and Ubac3 were increased by a factor of about 3. In contrast, bacterial levels for B. amyloliquefaciens, B. M9H, Enterococcus dc6, L sp. M3T8B4 and Ubac1, were seriously altered in step 2. Ubac2 strain-levels were reduced by a factor of 1000 over fat diet intake (Figure 4A). However, some of these bacteria (E. faecium, B. M9H, B. oleronius, Ubac2 and Ubac4) are found to be specifically regulated by Lactobacillus cocktail (Figures 4B). An increase of about $50 \%$ was noticed for E. faecium following Lactobacillus treatment. This may be very beneficial for the mice. E. faecium and some other strains of Enteroccocus bacteria are known to have positive effects on intestinal microbial flora and immune function in particular in mice [50,51]. Lactobacillus also significantly increased levels of Ubac2 in the mouse gut and strongly reduced (by about 30\%) the levels of Ubac4 (Figure 4B). Thus, our results show that Lactobacillus could have two-sided beneficial effects. It could help stimulate beneficial bacterial-strain levels such as Ubac2 and in the same time significantly reduce the levels of more harmful bacteria such as Ubac4. On the basis of these results, we propose that our new probiotic cocktail could have numerous beneficial effects on animal and human gut microflora and could be a particularly good alternative to treatments with Simvastatin and any other even more toxic statin drugs.

In addition, our results show that specific bacterial strainlevels such as those of Efae and Ubac4 that are found to be strongly associated to hyperlipidemic conditions might be useful probes for diagnosis of obesity risks and diabetes using fecal samples of patients with metabolic problems. This needs to be investigated very precisely in order to develop new formulations against most severe conditions of hyperlipidemia.
The function of the four uncultured bacteria Ubac1 (KC347585; 98\% identical to E. faecium strain S4, KC478508), Ubac2 (KC441062; 98\% identical to L. taiwanensis, NR-044507), Ubac3 (KC441063; also 98\% identical to L. taiwanensis, NR044507) and Ubac4 (KC441064; 98\% identical to L. murinus, AB326349) is unknown and needs to be investigated to study in details the beneficial effects of Lactobacillus. Lactobacillus species such as L. taiwanensis are known to increase in the gut of mice fed with high-fat diet in agreement with our study [52]. L. johnsonii strain-levels are shown to increase over fat diet intake (Figure 4). A certain number of Lactobacilli have also been described in the gut of rats reared with sucrose [53]. Lactobacilli are known to be crucial to regulate sugar as well as polyphosphate physiological levels [54]. They are also known to decrease inflammation and muscle atrophy in acute leukemia mouse models [55]. $L$. murinus strains have even been shown to enhance intestinal cell proliferation and therefore maintain gastrointestinal cell turnover [56]. Both Lactobacillus and Enteroccocus are known to play a key role in sugar and protein digestion for vitamin and short fatty acid synthesis as well as in immunomodulation, pathogen inhibition and epithelial cell attachment as part of the "acidophilus complex" [57]. A strain such as L. johnsonii is traditionally used to attenuate Helicobacter pylori-associated gastritis [58]. Thus, our current knowledge about the function of gut and fecal bacteria strongly suggests that high-fat diet could alter many various physiological functions by altering the composition of the gut microflora. Our results typically show that beneficial bacterial strain-levels could be dangerously downregulated while other much more toxic bacterial pathogens could be developed in the gut in response to ingestion and accumulation of high amounts of fat. Treatments such as our Lactobacillus cocktail may be extremely useful to maintain strain-levels in the gut microbial flora and thereby good health conditions.

However, it has to be taken into consideration that the 
A.

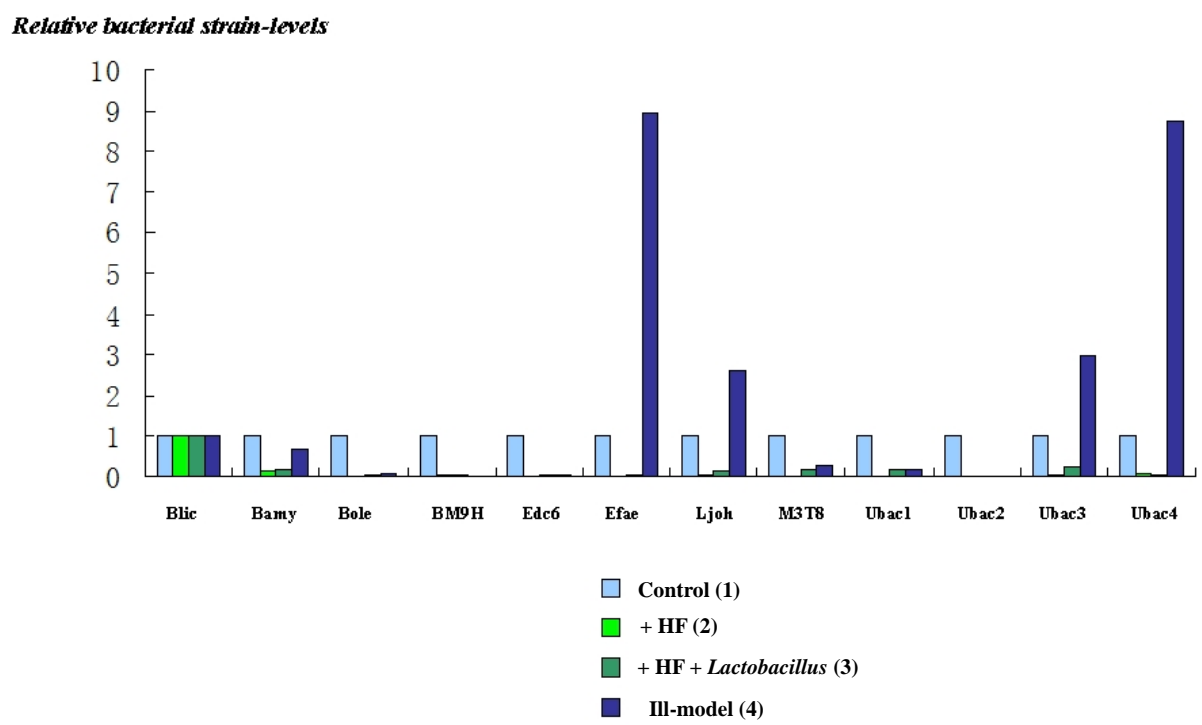

B.

Relative bacterial strain-levels

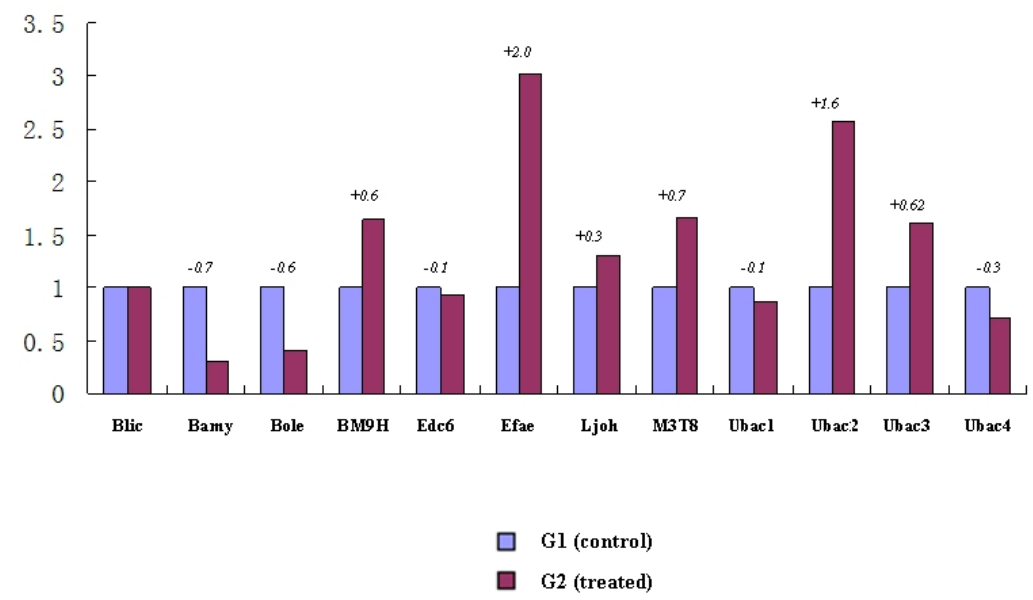

Figure 4: Quantitative real-time PCR analysis of bacterial strains from mouse gut and feces. A: Relative abundance of the twelve bacterial strains identified in fecal samples from mice fed with standard diet (1), mice fed with standard diet complemented with high fat (2), mice fed with high-fat diet complemented with Lactobacillus cocktail (3) and ill-model mice (4). Strain-levels in mice fed with standard diet are used as control (= 1). B: Relative abundance of the twelve bacterial strains identified in the gut samples from ill-model mice treated with placebo (G1) or Lactobacillus (G2). Strain-levels in the gut of ill mice from step 2 are used as control (=1). In A and B, bacterial-strain levels in each sample are compared to levels of the bacterial strain Blic used as reference (Table 4). The value $2^{\wedge}$ (-deltadeltaCt) is calculated using the mean Ct value ( $\left.n=9\right)$. Blic: Bacillus licheniformis, Bamy: Bacillus amyloliquefaciens, Bole: Bacillus oleronius, Bm9h: Bacillus M9H, Edc6: Enterococcus dc6, Efae: Enterococcus faecium, Ljoh: Lactobacillus johnsonii, M3T8: Lactococcus M3T8B4, Ubac1: Uncultured bacterium 1, Ubac2: Uncultured bacterium 2, Ubac3: Uncultured bacterium 3, Ubac4: Uncultured bacterium 4.

stimulatory effects of Lactobacillus on bacterial strain-levels including BM9H, Ubac2 or Efae were not observed during step 1 (development of illness over excessive fat diet intake). All the twelve strain levels were found to be severely down-regulated in step 1 in the absence or presence of Lactobacillus (Figures $3 \& 4)$. This indicates perhaps that one of the short-term effects of excessive fat intake is a completely down-regulation of the entire gut flora. A similar down-regulation of bacterial strain-levels is observed in the case of various disorders such as inflammatory bowel disease (IBD), Crohn's disease (CD), ulcerative colitis and colon cancer [59-62]. In contrast, long-term effects of fat diet intake could lead to increased levels of harmful bacteria in absence of Lactobacillus. We describe a case of hyperlipidemic mouse model where many strains such as BM9H, Efae and Ubac2 were completely abolished in step 1 and where two strains (Ubac4 and Enteroccocus) were increased by a factor of 10 in feces of hyperlipidemic mice after a long-term fat diet (step 2; Figure 4). If this is good or bad for the model mice needs to be explored in further details using BM9H, Enteroccocus, Ubac2 or Ubac4 single strain experiments. Different doses of Lactobacillus and/ 


\section{$\mathrm{Mmol} / \mathrm{l}$}

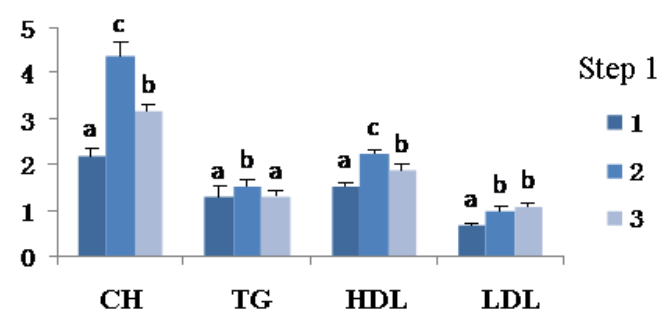

\section{$\mathrm{Mmol} / \mathrm{l}$}
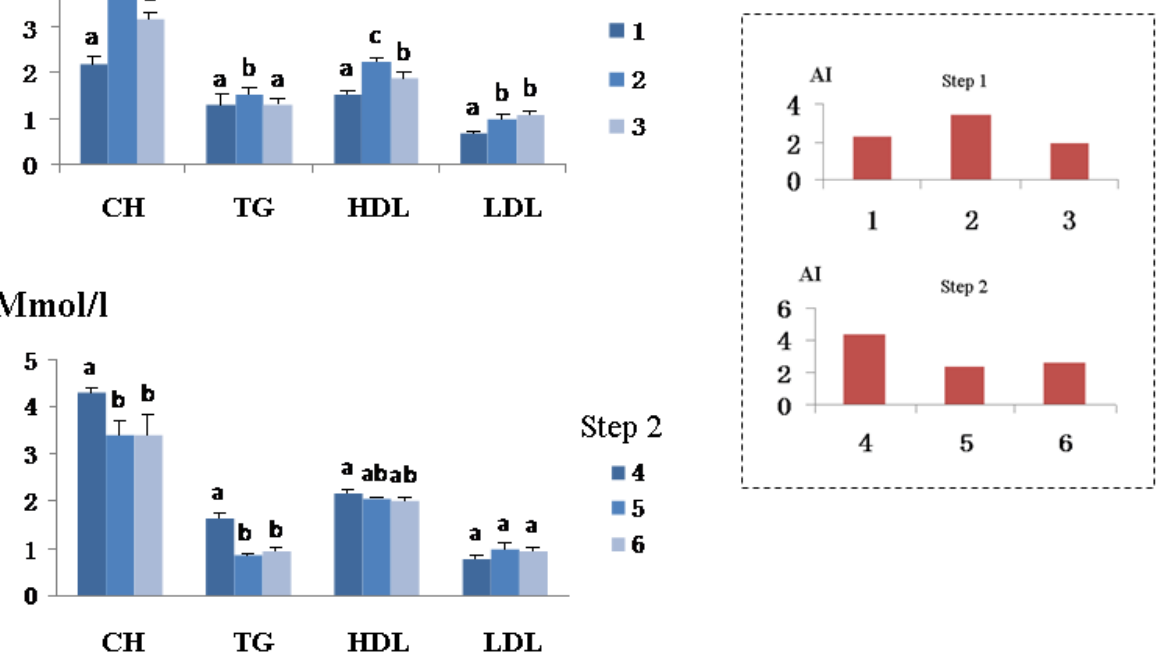

Figure 5: Blood lipid concentration (in Mmol/liter) of cholesterol (CH), triglycrides (TG), high density lipoprotein (HDL) and low density lipoprotein (LDL) in mice subjected to hyperlipidemia, bacterial bioproducts and pharmaceutical treatment conditions. 1: Standard diet, 2: Fat diet, 3: Fat diet and Lactobacillus complement (Step 1), 4: Hyperlipidemic mice, 5: Hyperlipidemic mice treated with Lactobacillus, 6: Hyperlipidemic mice treated with Simvastatin (Step 2). Bars represent mean \pm SEM. Bars followed by the same letter do not differ significantly ( $\mathrm{P} \leq 0.05$ ). The histogram window shows Atherosclerotic Index (AI) in the six groups of mice.

A.

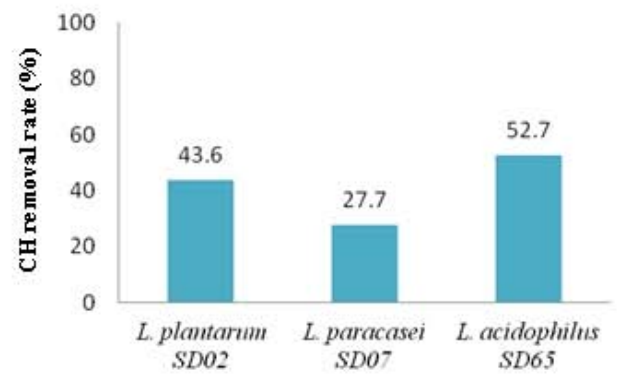

B.

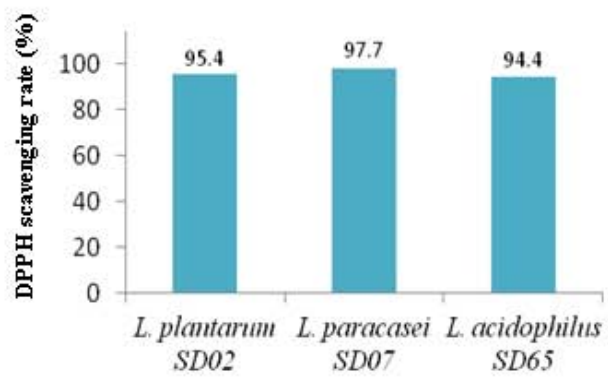

C.

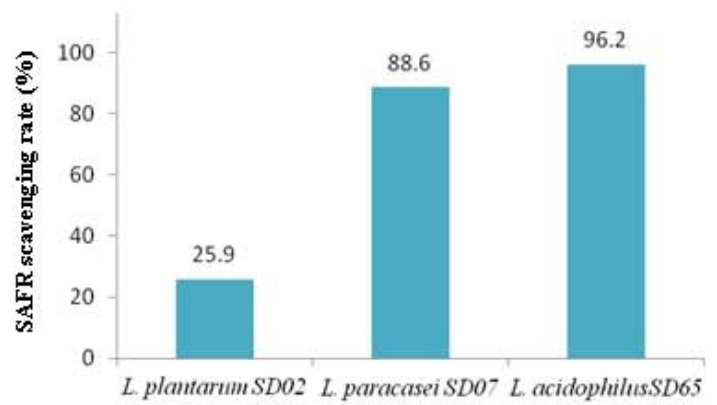

Figure 6: Lactobacillus single-strain effects on cholesterol $(\mathrm{CH})$ removal rate (A) and scavenging rate against 2,2-diphenyl-1-picrylhydrazyl (DPPH) (B) and superoxide anion free radicals (SAFR) (C). Number atop the bar is the mean percent value for each treatment. 
Table 4: Paired samples test in SPSS using mean Ct values of bacterial levels in mouse feces and gut from Step1 and Step2. Pairs with Sig. (2-tailed) > 0.05 do not differ significantly. Fecal samples were from S1 (Standard diet), S2 (High-Fat diet), S3 (High-Fat diet and Lactobacillus complement) of Step 1 and S4 (hyperlipidemia-ill mice of Step 2); gut samples were from hyperlipidemia ill-mice (G1) and hyperlipidemia ill-mice treated with Lactobacillus (G2) (Step 2). No differences were found for B. licheniformis (Blic) between S1-S4 ( $\mathrm{P}=0.166)$ and G1-G2 (P=0.964).

\begin{tabular}{|c|c|c|c|c|c|c|}
\hline \multirow{2}{*}{ Bacteria } & \multirow{2}{*}{ Fecal } & \multirow{2}{*}{ Mean Difference } & \multirow{2}{*}{ Std Error } & \multirow{2}{*}{ Sig. } & \multicolumn{2}{|c|}{ 95\% Confidence interval } \\
\hline & & & & & Lower Bound & Upper Bound \\
\hline \multirow{6}{*}{ Blic } & $1-2$ & $-6.27000^{*}$ & 1.13160 & 0.001 & -8.8795 & -3.6605 \\
\hline & $1-3$ & $-2.72667^{*}$ & 1.13160 & 0.043 & -5.3361 & -0.1172 \\
\hline & $1-4$ & -1.21333 & 1.13160 & 0.315 & -3.8228 & 1.3961 \\
\hline & $2-3$ & $3.54333^{*}$ & 1.13160 & 0.014 & .9339 & 6.1528 \\
\hline & $2-4$ & $5.05667^{*}$ & 1.13160 & 0.002 & 2.4472 & 7.6661 \\
\hline & $3-4$ & 1.51333 & 1.13160 & 0.218 & -1.0961 & 4.1228 \\
\hline \multirow{6}{*}{ Bamy } & $1-2$ & $-3.69667^{*}$ & 0.27197 & 0.000 & -4.3238 & -3.0695 \\
\hline & $1-3$ & -0.32000 & 0.27197 & 0.273 & -.9472 & 0.3072 \\
\hline & $1-4$ & $-0.93000^{*}$ & 0.27197 & 0.009 & -1.5572 & -.3028 \\
\hline & $2-3$ & $3.37667^{*}$ & 0.27197 & 0.000 & 2.7495 & 4.0038 \\
\hline & $2-4$ & $2.76667^{*}$ & 0.27197 & 0.000 & 2.1395 & 3.3938 \\
\hline & $3-4$ & -0.61000 & 0.27197 & 0.055 & -1.2372 & 0.0172 \\
\hline \multirow{6}{*}{ Bole } & $1-2$ & -0.04333 & 0.38394 & 0.913 & -0.9287 & .8420 \\
\hline & $1-3$ & $1.94333^{*}$ & 0.38394 & 0.001 & 1.0580 & 2.8287 \\
\hline & $1-4$ & $1.53667^{*}$ & 0.38394 & 0.004 & 0.6513 & 2.4220 \\
\hline & $2-3$ & $1.98667^{*}$ & 0.38394 & 0.001 & 1.1013 & 2.8720 \\
\hline & $2-4$ & $1.58000^{*}$ & 0.38394 & 0.003 & 0.6946 & 2.4654 \\
\hline & $3-4$ & -0.40667 & 0.38394 & 0.320 & -1.2920 & 0.4787 \\
\hline \multirow{6}{*}{$B M 9 H$} & $1-2$ & $-1.54667^{*}$ & 0.23682 & 0.000 & -2.0928 & -1.0006 \\
\hline & $1-3$ & $1.38333^{*}$ & 0.23682 & 0.000 & .8372 & 1.9294 \\
\hline & $1-4$ & $-4.46333^{*}$ & 0.23682 & 0.000 & -5.0094 & -3.9172 \\
\hline & $2-3$ & $2.93000^{*}$ & 0.23682 & 0.000 & 2.3839 & 3.4761 \\
\hline & $2-4$ & $-2.91667^{*}$ & 0.23682 & 0.000 & -3.4628 & -2.3706 \\
\hline & $3-4$ & $-5.84667^{*}$ & 0.23682 & 0.000 & -6.3928 & -5.3006 \\
\hline \multirow{6}{*}{$E d c 6$} & $1-2$ & $3.46000^{*}$ & 0.12891 & 0.000 & 3.1627 & 3.7573 \\
\hline & $1-3$ & $1.98667^{*}$ & 0.12891 & 0.000 & 1.6894 & 2.2839 \\
\hline & $1-4$ & $2.50000^{*}$ & 0.12891 & 0.000 & 2.2027 & 2.7973 \\
\hline & $2-3$ & $-1.47333^{*}$ & 0.12891 & 0.000 & -1.7706 & -1.1761 \\
\hline & $2-4$ & $-0.96000^{*}$ & 0.12891 & 0.000 & -1.2573 & -.6627 \\
\hline & $3-4$ & 0.51333* & 0.12891 & 0.004 & 0.2161 & .8106 \\
\hline \multirow{6}{*}{ Efae } & $1-2$ & $-0.92333^{*}$ & 0.13427 & 0.000 & -1.2330 & -.6137 \\
\hline & $1-3$ & $1.19000^{*}$ & 0.13427 & 0.000 & .8804 & 1.4996 \\
\hline & $1-4$ & $-4.64333^{*}$ & 0.13427 & 0.000 & -4.9530 & -4.3337 \\
\hline & $2-3$ & $2.11333^{*}$ & 0.13427 & 0.000 & 1.8037 & 2.4230 \\
\hline & $2-4$ & $-3.72000^{*}$ & 0.13427 & 0.000 & -4.0296 & -3.4104 \\
\hline & $3-4$ & $-5.83333^{*}$ & 0.13427 & 0.000 & -6.1430 & -5.5237 \\
\hline \multirow{6}{*}{ Ljoh } & $1-2$ & $-2.46667^{*}$ & 0.26379 & 0.000 & -3.0750 & -1.8584 \\
\hline & $1-3$ & 0.13333 & 0.26379 & 0.627 & -.4750 & 0.7416 \\
\hline & $1-4$ & $-2.86333^{*}$ & 0.26379 & 0.000 & -3.4716 & -2.2550 \\
\hline & $2-3$ & $2.60000^{*}$ & 0.26379 & 0.000 & 1.9917 & 3.2083 \\
\hline & $2-4$ & -0.39667 & 0.26379 & 0.171 & -1.0050 & 0.2116 \\
\hline & $3-4$ & $-2.99667^{*}$ & 0.26379 & 0.000 & -3.6050 & -2.3884 \\
\hline
\end{tabular}

Citation: Yue S, Chinnapandi B, Ge H, Zou X, Chen X, Wang C, et al. (2014) A Lactobacillus Cocktail Changes Gut Flora and Reduces 


\begin{tabular}{|c|c|c|c|c|c|c|}
\hline \multirow{6}{*}{ М3Т8B4 } & $1-2$ & $0.33667^{*}$ & 0.11928 & 0.022 & 0.0616 & 0.6117 \\
\hline & $1-3$ & $-0.41000^{*}$ & 0.11928 & 0.009 & -0.6851 & -.1349 \\
\hline & $1-4$ & $0.35333^{*}$ & 0.11928 & 0.018 & 0.0783 & 0.6284 \\
\hline & $2-3$ & $-0.74667^{*}$ & 0.11928 & 0.000 & -1.0217 & -0.4716 \\
\hline & $2-4$ & 0.01667 & 0.11928 & 0.892 & -.2584 & 0.2917 \\
\hline & $3-4$ & $0.76333^{*}$ & 0.11928 & 0.000 & .4883 & 1.0384 \\
\hline \multirow{6}{*}{ Ubac1 } & $1-2$ & $-0.90667^{*}$ & 0.16974 & 0.001 & -1.2981 & -0.5152 \\
\hline & $1-3$ & -0.17333 & 0.16974 & 0.337 & -0.5648 & 0.2181 \\
\hline & $1-4$ & $0.92000^{*}$ & 0.16974 & 0.001 & 0.5286 & 1.3114 \\
\hline & $2-3$ & $0.73333^{*}$ & 0.16974 & 0.003 & 0.3419 & 1.1248 \\
\hline & $2-4$ & $1.82667^{*}$ & 0.16974 & 0.000 & 1.4352 & 2.2181 \\
\hline & $3-4$ & $1.09333^{*}$ & 0.16974 & 0.000 & 0.7019 & 1.4848 \\
\hline \multirow{6}{*}{ Ubac2 } & $1-2$ & $2.24000^{*}$ & 0.52052 & 0.003 & 1.0397 & 3.4403 \\
\hline & $1-3$ & $4.21667^{*}$ & 0.52052 & 0.000 & 3.0163 & 5.4170 \\
\hline & $1-4$ & $4.91667^{*}$ & 0.52052 & 0.000 & 3.7163 & 6.1170 \\
\hline & $2-3$ & $1.97667^{*}$ & 0.52052 & 0.005 & 0.7763 & 3.1770 \\
\hline & $2-4$ & $2.67667^{*}$ & 0.52052 & 0.001 & 1.4763 & 3.8770 \\
\hline & $3-4$ & .70000 & 0.52052 & 0.216 & -.5003 & 1.9003 \\
\hline \multirow{6}{*}{ Ubac3 } & $1-2$ & $-1.35000^{*}$ & 0.40266 & 0.010 & -2.2785 & -0.4215 \\
\hline & $1-3$ & -.56000 & 0.40266 & 0.202 & -1.4885 & 0.3685 \\
\hline & $1-4$ & $-3.05667^{*}$ & 0.40266 & 0.000 & -3.9852 & -2.1281 \\
\hline & $2-3$ & 0.79000 & 0.40266 & 0.085 & -0.1385 & 1.7185 \\
\hline & $2-4$ & $-1.70667^{*}$ & 0.40266 & .003 & -2.6352 & -.7781 \\
\hline & $3-4$ & $-2.49667^{*}$ & 0.40266 & .000 & -3.4252 & -1.5681 \\
\hline \multirow{6}{*}{ Ubac4 } & $1-2$ & $-2.78333^{*}$ & 0.17491 & .000 & -3.1867 & -2.3800 \\
\hline & $1-3$ & $1.38667^{*}$ & 0.17491 & 0.000 & 0.9833 & 1.7900 \\
\hline & $1-4$ & $-4.61667^{*}$ & 0.17491 & 0.000 & -5.0200 & -4.2133 \\
\hline & $2-3$ & $4.17000^{*}$ & 0.17491 & 0.000 & 3.7667 & 4.5733 \\
\hline & $2-4$ & $-1.83333^{*}$ & 0.17491 & 0.000 & -2.2367 & -1.4300 \\
\hline & $3-4$ & $-6.00333^{*}$ & 0.17491 & 0.000 & -6.4067 & -5.6000 \\
\hline \multirow[t]{2}{*}{ Bacteria } & \multirow[t]{2}{*}{ Gut } & \multirow[t]{2}{*}{ Mean } & \multirow[t]{2}{*}{ Std error } & \multirow[t]{2}{*}{ Sig } & \multicolumn{2}{|c|}{$\begin{array}{l}\text { 95\% Confidence interval of the } \\
\text { difference }\end{array}$} \\
\hline & & & & & Lower & Upper \\
\hline Blic & $1-2$ & 1.15667 & 1.29497 & 0.406 & -2.0120 & 4.3253 \\
\hline Bamy & $1-2$ & $2.8667^{*}$ & 0.19435 & 0.000 & 2.3911 & 3.3422 \\
\hline Bole & $1-2$ & $0.74333^{*}$ & 0.27954 & 0.038 & 0.0593 & 1.4273 \\
\hline$B M 9 H$ & $1-2$ & $1.67000^{*}$ & 0.20607 & 0.000 & 1.1658 & 2.1742 \\
\hline$E d c 6$ & $1-2$ & $1.23333^{*}$ & 0.15266 & 0.000 & 0.8598 & 1.6069 \\
\hline Efae & $1-2$ & $0.78000^{*}$ & 0.18211 & 0.005 & 0.3344 & 1.2256 \\
\hline Ljoh & $1-2$ & $0.78000^{*}$ & 0.26021 & 0.024 & 0.1433 & 1.4167 \\
\hline M3T8B4 & $1-2$ & $0.40333^{*}$ & 0.09039 & 0.004 & 0.1822 & 0.6245 \\
\hline Ubac1 & $1-2$ & $1.35667^{*}$ & 0.18899 & 0.000 & 0.8942 & 1.8191 \\
\hline Ubac2 & $1-2$ & -0.20333 & 0.19431 & 0.336 & -0.6788 & 0.2721 \\
\hline Ubac3 & $1-2$ & 0.45667 & 0.44272 & 0.342 & -0.6266 & 1.5400 \\
\hline Ubac4 & $1-2$ & $1.61667^{*}$ & 0.11271 & 0.000 & 1.3409 & 1.8925 \\
\hline
\end{tabular}

${ }^{*}$ The mean difference is significant at the 0.05 level. 
Table 5: Bodyweight and weight of internal organs of mice subjected to hyperlipidemia, bacterial cocktail bioproducts and pharmaceutical treatment conditions.

\begin{tabular}{|c|c|c|c|c|c|c|c|}
\hline Mice & $\begin{array}{c}\text { Body } \\
\text { weight (g) }\end{array}$ & $\begin{array}{c}\text { Liver } \\
\text { weight (g) }\end{array}$ & $\begin{array}{c}\text { Kidney } \\
\text { weight (g) }\end{array}$ & $\begin{array}{c}\text { Spleen } \\
\text { weight (g) }\end{array}$ & $\begin{array}{c}\text { Pancreas } \\
\text { weight (g) }\end{array}$ & $\begin{array}{c}\text { Epididymal } \\
\text { fat pad (g) }\end{array}$ & $\begin{array}{c}\text { Perirenal } \\
\text { fat pad (g) }\end{array}$ \\
\hline$(1)$ & $31.7 \pm 0.81 \mathrm{~A}$ & $1.57 \pm 0.11 \mathrm{a}$ & $0.515 \pm 0.036 \mathrm{a}$ & $0.122 \pm 0.014 \mathrm{a}$ & $0.055 \pm 0.0056 \mathrm{a}$ & $0.785 \pm 0.055 \mathrm{~A}$ & $0.219 \pm .019 \mathrm{~A}$ \\
\hline$(2)$ & $38.4 \pm 2.03 \mathrm{~B}$ & $1.89 \pm 0.13 \mathrm{a}$ & $0.509 \pm 0.022 \mathrm{a}$ & $0.134 \pm 0.011 \mathrm{a}$ & $0.0796 \pm 0.0078 \mathrm{a}$ & $1.978 \pm 0.123 \mathrm{~B}$ & $0.398 \pm .045 \mathrm{~B}$ \\
\hline$(3)$ & $30.6 \pm 0.85 \mathrm{~A}$ & $1.59 \pm 0.056 \mathrm{a}$ & $0.441 \pm 0.035 \mathrm{a}$ & $0.145 \pm 0.075 \mathrm{a}$ & $0.0716 \pm 0.0101 \mathrm{a}$ & $0.951 \pm 0.048 \mathrm{~A}$ & $0.131 \pm .023 \mathrm{~A}$ \\
\hline$(4)$ & $39.2 \pm 0.90 \mathrm{a}$ & $1.88 \pm 0.056 \mathrm{a}$ & $0.553 \pm 0.044 \mathrm{a}$ & $0.108 \pm 0.0097 \mathrm{a}$ & $0.073 \pm 0.0081 \mathrm{a}$ & $1.27 \pm 0.13 \mathrm{~A}$ & $0.263 \pm 0.049 \mathrm{a}$ \\
\hline$(5)$ & $39.8 \pm 1.79 \mathrm{a}$ & $1.93 \pm 0.052 \mathrm{a}$ & $0.546 \pm 0.035 \mathrm{a}$ & $0.143 \pm 0.0037 \mathrm{~b}$ & $0.083 \pm 0.015 \mathrm{a}$ & $1.75 \pm 0.25 \mathrm{~A}$ & $0.316 \pm 0.031 \mathrm{a}$ \\
\hline$(6)$ & $44.17 \pm 1.84 \mathrm{a}$ & $2.06 \pm 0.15 \mathrm{a}$ & $0.633 \pm 0.027 \mathrm{a}$ & $0.126 \pm 0.011 \mathrm{a}$ & $0.104 \pm 0.0018 \mathrm{a}$ & $2.24 \pm 0.15 \mathrm{~B}$ & $0.495 \pm 0.064 \mathrm{~b}$ \\
\hline
\end{tabular}

Values represent mean \pm SEM. Values followed by different small and capital letters indicate significant level at $\mathrm{P} \leq 0.05$ and $\mathrm{P} \leq 0.01$, respectively. (1): Standard diet, (2): Fat diet, (3): Fat diet and Lactobacillus complement (Step 1), (4): Hyperlipidemia-mice, (5): Hyperlipidemia-mice treated with Lactobacillus, (6): Hyperlipidemia-mice treated with Simvastatin (Step 2).

or more appropriate ratios of bacteria in the bio-product cocktail may help boost specific bacterial strain-levels of the gut flora in the short term. A slight increase is seen for L. johnsonii, M3T8B4, Ubac1 and Ubac3 during co-ingestion of fat diet and Lactobacillus (Figure 4). Long-term and short-term effects of Lactobacillus on the composition of the gut flora may be very different. They may well depend on individuals [63-67]. However, our results in mice show that the effects of Lactobacillus mainly depend on the concentration of ingested fat. Analyzing Efae and Ubac2 strainlevels, Lactobacillus is found to have a stimulatory effect during standard food diet intake but a rather inhibitory effect during intake of high fat diet (Figures 4A-B). In contrast, Ubac4 levels are reduced by Lactobacillus in both Step 1 and Step 2 (Figures 4A-B). All together, this suggests that effects of Lactobacillus may strongly depend on the diet but that very specific noxious gut bacterial strains such as Ubac4 could be targeted independently to diet conditions.

In Human, there is a clear correlation between gut flora, phenotype diversity, food diet and blood pressure [68]. However, very little is known about microflora, regulation of singlebacterial strains, metagenomics, genes and control of high blood lipid levels. In mice, the gut flora is known to regulate fat metabolism [69]. Interestingly, in our study, overweight, fat pad accumulations, hypercholesterolemia and high blood lipid concentration are diagnosed for mice overfed with fat diet in step 1 where gut bacterial diversity is seriously affected (Figures 2-5 \& Tables 3-5). This illustrates a strong association between gut flora and lipid metabolism. Importantly, our results show that overfeeding mice with high-fat diet lead to significant weight gain and increased epididymal fat pad mass, but that the addition of Lactobacillus in the diet clearly maintains normal body weight and weight of specific tissues such as the liver, the adipose capsule of the kidney and the epididymal fat (Table 5, Step 1). In the pool of fat mice, we show that treatments with Lactobacillus and Simvastatin over fourteen-days period did not re-establish normal conditions in regard to body weight and/or specific organ weight. Epididymal fat pad even increased after probiotic or medical treatment (Table 5, Step 2). However, it appeared very clearly that Lactobacillus bio-product treatments in high-fat diet fed mice had more significant effects on body weight and weight of kidney, pancreas and perirenal/epididymal fat pads than

\section{Simvastatin-based therapy (Table 5, Step 2).}

In regard to blood biochemical parameters, our results show that overfeeding mice with high-fat diet lead to a severe accumulation of neutral lipids in the blood circuitry (Figure 5, Step 1). No differences were found in cholesterol and triglyceride level numbers as well as in LDL/HDL ratios between fat mice treated with Lactobacillus and those treated with Simvastatin. In the two treatments, decreased cholesterol and triglyceride blood concentrations were detected in comparison with untreated ill-mice (Figure 5, Step 2), suggesting that bioproducts and drugs could both have beneficial effects on lipid metabolism in individuals with a fatty-acid metabolism disorder. However, bioproducts are shown to improve cholesterolemia also during fat intake (Figure 5). Other studies in rodent models as well as in Human indicate that probiotic bacteria could be used to improve the lipid profile as an alternative or a supplement for antibiotic therapy [70-72]. However, our results show clear support for the further idea that Lactobacillus can prevent hyperlipidemia when added as a complement of fat food. Significantly lower cholesterol, triglyceride, HDL/LDL ratios were found in the blood from mice of step 1 treated with Lactobacillus (Figure 5). In addition, while atherosclerotic index as high as 3.47-4.43 was observed in mice fed with high-fat diet (indicative of severe disease conditions), AI values were reduced to 2.00-2.41 in Lactobacillus-treated mice similarly to control healthy and Simvastatin-treated mice (Figure 5). In a further attempt to justify how the Lactobacillus works for the in vivo pharmacology, we measured additional biochemical parameters for the lipid metabolism and oxidation in mice (cholesterol removal rate and scavenging rates of diphenylpicrylhydrazyl and superoxide anion free radicals). We find that $L$. plantarum SD02, L. paracasei SD07 and L. acidophilus SD65 used as single-strain significantly contribute to cholesterol removal. A CH removal rate of $30-50 \%$ is observed following treatment with each strain of Lactobacilli (Figure 6A). In addition, each Lactobacillus strain of the bioproduct is shown to have a very high scavenging ability against DPPH (1,1-diphenyl-2-picrylhydrazyl). In DPPH-scavenging assay total antioxidant capacity was found to be superior to $90 \%$ for all the three single-bacterial strains tested at the dose implemented in the bioproduct $\left(10^{9} \mathrm{CFU} / \mathrm{ml}\right)$. These results indicated a strong antioxidant activity in the bioproduct (Figure 6B). Finally, L. plantarum is found to have a rather low 
scavenging ability against SAFRs, but the two other Lactobacillus single strains (L. paracasei and L. acidophilus) are both found to have potent superoxide anion scavenger activities. The SAFR scavenging rate value of $L$. plantarum is only of about $25 \%$, but the SAFR scavenging rate values observed with $L$. paracasei and L. acidophilus are of about 88 and 96\%, respectively (Figure 6C). This is particularly important since $\mathrm{O}_{2}^{-}$anion is known as one of the major causes of apoptosis and cell death in various tissues following all many different mechanisms [73,74].

Our results therefore demonstrate that a food complemented with our new Lactobacillus cocktail can not only have a strong beneficial effect for the gut flora but also for many biochemical parameters of general body condition especially in affections related to cholesterolemia and thereby altered hepatic metabolism [75-78].

\section{Conclusion}

A specific cocktail of Lactobacillus bacteria is found to act on the gut flora and to have both curative and preventive effects on the accumulation of lipids in the blood and fat in various organ tissues of the digestive tract. We show that a precise composition of L. plantarum SD02, L. acidophilus SD65 and L. casei SD07 helps maintain gut flora, reduce blood lipid concentration, control cholesterol levels, stimulate antioxidant activities and avoid gain of weight in a hyperlipidemia mouse model system. If the cocktail works in an obese mouse model system, a domestic animal such as dog and cat and/or an animal model of the industrial production such as chicken, cow, duck, goat, goose, hen, horse, mouton, ox, piglet and rabbit needs to be investigated in details. Our Lactobacillus cocktail may be beneficial in dolphins. It may also be beneficial in fishes, mollusks and turtles. Importantly, it may be very crucial to help digestion and thereby reproduction of endangered animals such as Cheetah, Gorilla, Panda, Rhino, Tiger and other legendary animals such as the Deer of Hainan Island. It may also help improve digestion in wild animals such as wolves and white bears and thereby their adaptation to new unnatural environment. In addition, the cocktail of $L$. plantarum SD02, L. acidophilus SD65 and L. casei SD07 may before all have very beneficial effects in patients suffering both lipid metabolism pathology and Simvastatin therapy. We think that our Lactobacillus preparation applied for human health can be extremely benefic not only to eliminate the secondary effects due to chemical drugs such as Simvastatin but also to put a brake on the development of pathological conditions including cancer, diabetes and obesity.

\section{Acknowledgements}

J.F.P. is High Level Oversea Scientist and Taishan Scholar (NO.tshw20091015). We acknowledge the support of grants ZR2011CM046 from Natural Sciences Foundation of Shandong Province and 2012BAK17B05 from National Key Technologies R \& D Program.

\section{References}

1. Chaput JP, Doucet E, Tremblay A (2012) Obesity: a disease or a biological adaptation? An update. Obes Rev 13(8): 681-691.

2. Low S, Chin MC, Deurenberg-Yap M (2009) Review on epidemic of obesity. Ann Acad Med Singapore 38(1): 57-59.

3. Kodama S, Horikawa C, Fujihara K, Yoshizawa S, Yachi Y, et al. (2014) Quantitative relationship between body weight gain in adulthood and incident type 2 diabetes: a meta-analysis. Obesity Rev 15(3): 202-214.

4. Zuckerman Levin N, Hochberg Z, Latzer Y (201 4) Bone health in eating disorders. Obesity Rev 153(3): 215-223.

5. Sedjo RL, Byers T, Ganz PA, Colditz GA, Demark-Wahnefried W, et al. (2014) Weight gain prior to entry into a weight-loss intervention study among overweight and obese breast cancer survivors. J Cancer Surviv. DOI: 10.1007/s11764-014-0351-9.

6. Schneider HJ, Wallaschofski H, Volzke H, Markus MRP, Doerr M, et al. (2012) Incremental effects of endocrine and metabolic biomarkers and abdominal obesity on cardiovascular mortality prediction 7 (3): e33084.

7. Ley RE, Backhed F, Turnbaugh PJ, Lozupone CA, Knight RD, et al (2005) Obesity alters gut microbial ecology. Proc Natl Acad Sci USA 102(31): 11070-11075.

8. Turnbaugh PJ, Hamady M, Yatsunenko T, Cantarel BL, Duncan A, et al. (2009) A core gut microbiome in obese and lean twins. Nature 457(7228): 480-484.

9. Jones N (2013) Gut-microbe swaps helps mice shed weight. Nature. doi:10.1038/nature.2013.12688.

10. Liou AP, Paziuk M, Luevano JM Jr, Machineni S, Turnbaugh PJ, et al. (2013) Conserved shift in the gut microbiota due to gastric bypass reduce host weight and adiposity. Sci Transl Med 5(178): 178ra41.

11. Tremaroli V, Bäckhed F (2012) Functional interactions between the gut microbiota and host metabolism. Nature 489(7415): 242-249.

12. Guarner F, Malagelada JR (2003) Gut flora in health and disease. Lancet 361(9356): 512-519.

13. Wang Z, Klipfell E, Bennett B, RobertKoeth, Bruse S Levison, et al. (2011) Gut flora metabolism of phosphatidylcholine promotes cardiovascular disease. Nature 472(7341): 57-63.

14. Martin FP, Wang Y, Sprenger N, Yap IK, Lundstëdt T, et al. (2008) Probiotic modulation of symbiotic gut microbial-host metabolic interactions in a humanized microbiome mouse model. Mol Syst Biol 4: 57.

15. Harris K, Kassis A, Major G, Chou CJ (2012) Is the gut microbiota a new factor contributing to obesity and its metabolic disorders? J. Obesity 2012: 879151.

16. Nadal I, Santacruz A, Marcos A, Warnberg J, Garagorri M, et al. (2009) Shifts in clostridia, bacteroides and immunoglobulin-coating fecal bacteria associated with weight loss in obese adolescents. Int J Obes (Lond) 33(7): 758-767.

17. Santacruz A, Marcos A, Wärnberg J, Martí A, Martin-Matillas M, et al. (2009) Interplay between weight loss and gut microbiota composition in overweight adolescents. Obesity (Silver Spring) 17(10): 19061915.

18. Angelakis E, Raoult D (2010) The increase of Lactobacillus species in the gut flora of newborn broiler chicks and ducks is associated with weight gain. PLoS ONE 5(5): e10463.

19. Raoult D (2009) Probiotics and obesity: a link. Nature Rev Microbiol $7(9): 616$. 
20. Duncan SH, Lobley GE, Holtrop G, Ince G, Johnstone AM, et al. (2008) Human colonic microbiota associated with diet, obesity and weight loss. Int J Obesity 32(11): 1720-1724.

21. Schwiertz A, Taras D, Schäfer K, Beijer S, Bos NA, et al. (2010) Microbiota and SCFA in lean and overweight healthy subjects. Obesity (Silver Spring) 18(1): 190-195.

22. Turpin W, Humblot C, Thomas M, Guyot JP (2010) Lactobacilli as multifaceted probiotics with poorly disclosed mechanisms. Int J Food Microbiol 143(3): 87-102.

23. Jumpertz R, Le DS, Turnbaugh PJ, Trinidad C, Bogardus C, et al. (2011) Energy-balance studies reveal associations between gut microbes, caloric load, and nutrient absorption in humans. Am J Clin Nutr 94(1): 58-65.

24.Zupancic ML, Cantarel BL, Liu ZQ, Drabek EF, Ryan KA, et al. (2012) Analysis of the gut microbiota in the old order Amish and its relation to the metabolic syndrome. PLoS ONE 7(8): e43052.

25. Ehrlich SD (2009) Probiotics - little evidence for a link to obesity. Nat Rev Microbiol 7(12): 901.

26. Delzenne N, Reid G (2009) No causal link between obesity and probiotics. Nat Rev Microbiol 7 (12): 901.

27. Olivares M, Díaz-Ropero MP, Sierra S, Lara-Villoslada F, Fonollá J, et al. (2007) Oral intake of Lactobacillus fermentum CECT5716 enhances the effects of influenza vaccination. Nutrition 23(3): 254-260.

28. Million M, Thuny F, Angelakis E, Casalta JP, Giorgi R, et al. (2013) Lactobacillus reuteri and Esterichia coli in the human gut microbiota may predict weight gain associated with vancomycin treatment. Nutr Diabetes: 3(9): e87.

29.Yu Z, Morrison M (2004) Improved extraction of PCR-quality community DNA from digesta and fecal samples. Biotech 36(5): 809812.

30. Livak KJ, Schmittgen TD (2001) Analysis of relative gene expression data using real-time quantitative PCR and the 2-deltadelta Ct method. Methods 25(4): 402-408.

31. Brashears MM, Gilliland SE, Buck LM (1998) Bile salt deconjugation and cholesterol removal from media by Lactobacillus casei . J Dairy Sci 81(8): 2103-2110.

32. Wang AN, Yi XW, Yu HF, Dong B, Qiao SY (2009) Free radical scavenging activity of Lactobacillus fermentum in vitro and its antioxidative effect on growing-finishing pigs. J Appl Microbiol 107(4): 1140-1148.

33. Sah BN, Vasiljevic T, McKechnie S, Donkor ON (2014) Effects of probiotics on antioxidant and antimutagenic activities of crude extract from yogurt. Food Chem 156: 264-270.

34. Heijitz RD, Wang SG, Anuar F, Qian Y, Björkholm B, et al. (2011) Normal gut microbiota modulates brain development and behavior. Proc Natl Acad Sci USA 108(7): 3047-3052.

35. Corthesy B, Gaskins HR, Mercenier A (2007) Cross-talk between probiotic bacteria and the host immune system. J Nutr 137(3): 78157905.

36. Toivanen P, Vaahtovuo J, Eerola E (2001) Influence of major histocompatibility complex on bacterial composition of fecal flora. Infect Immun 69(4): 2372-2377.

37. Salzman NH, de Jong H, Paterson Y, Harmsen HJM, Welling GW et al.(2002) Analysis of $16 \mathrm{~S}$ libraries of mouse gastrointestinal microflora reveals a large new group of mouse intestinal bacteria. Microbiology 148(11): 3651-3660.

38. Turnbull PC (1996) Bacillus. In: Medical Microbiology (Baron S, Ed), $4^{\text {th }}$ edition, Galveston, Texas, USA.

39. Pellizari R, Guidi-Rontani C, Vitale G, Mock M, Montecucco C (2000) Lethal factor of Bacillus anthracis cleaves the N-terminus of MAPKKs: analysis of the intracellular consequences in macrophages. Int J Med Microbiol 290(4-5): 412-427.

40. Bottone EJ (2010) Bacillus cereus, a volatile human pathogen. Clin Microbiol Rev 23(2): 382-398.

41. Smith A, Saiman L, Zhou J, Della-Latta P, Jia H, Graham PL $3^{\text {rd }}$ (2010) Concordance of gastrointestinal tract colonization and subsequent bloodstream infections with Gram-negative Bacilli in very low birth weight infants in the neonatal intensive care unit. Pediatr Infect Dis 29(9): 831-835.

42. Willems RJ, van Schaik W (2009) Transition of Enterococcus faecium from commensal organism to nosocomial pathogen. Future Microbiol $4(9): 1125-1135$.

43. Vu J, Carvalho J (2011) Enterococcus: review of its physiology, pathogenesis, diseases and the challenges it poses for clinical microbiology. Front Biol 6(5): 357-366.

44. Chang D, Zhu YF, An L, Liu JW, Su LX, et al. (2013) A multi-omic analysis of an Enterococcus faecium mutant reveals specific genetic mutations and dramatic changes in mRNA and protein expression. BMC Microbiol 13: 304.

45. Preiss D, Seshasai SR, Welsh P, Murphy SA, Ho JE et al. (2011). Risk of incident diabetes with intensive-dose compared with moderate-dose statin therapy: a meta-analysis. JAMA 305(24): 2556-2564.

46. Butaye P, Devriese LA, Haesebrouck F (2003) Antimicrobial growth promoters used in animal feed: effects of less well known antibiotics on Gram-positive bacteria. Clin Microbiol Rev 16(2): 175-188.

47.Jernberg C, Lofmark C, Edlund C, Jansson JK (2010) Long-term impacts of antibiotic exposure on the human intestinal microbiota. Microbiology 156(11): 3216-3223.

48. Flanagan JL, Brodie EL, Weng L, Lynch SV, Garcia O, et al. (2007) Loss of bacterial diversity during antibiotic treatment of intubated patients colonized with Pseudomonas aeruginosa. J Clin Microbiol 45(6): 19541962.

49. Stensballe LG, Simonsen J, Jensen SM, Bonnelykke K, Bisgaard H (2013) Use of antibiotics during pregnancy increases the risk of asthma in early childhood. J Pediatr 162(4): 832-838.

50. Benyacoub J, Pérez PF, Rochat F, Saudan KY, Reuteler G, et al. (2005) Enterococcus faecium SF68 enhances the immune response to Gardia intestinalis in mice. J Nutr 135(5): 1171-1176.

51.Sun P, Wang JQ, Jiang YM (2010) Effects of Enterococcus faecium (SF68) on immune function in mice. Food Chem 123(1): 63-68.

52.Zeng HW, Liu J, Jackson MI, Zhao FQ, Yan L, et al. (2013) Fatty liver accompanies an increase in Lactobacillus species in the hind gut of C57BL/6 mice fed at high-fat diet. J Nutr 143(5): 627-631.

53. Sarmianto-Rubiano LA, Berger B, Moine D, Zúňiga M, Pérez-Martínez G, et al. (2010) Characterization of a novel Lactobacillus species closely related to Lactobacillus johnsonii using a combination of molecular and comparative genomics methods. BMC Genomics 11: 504.

54. Alcántara C, Blasco A, Zúňiga M, Monedero V (2014) Accumulation 
of polyphosphate in Lactobacillus spp. and its involvement in stress resistance. Appl Environ Microbiol 80(5): 1650-1659.

55. Bindels LB, Beck R, Schakman O, Martin JC, De Backer F et al. (2012) Restoring specific Lactobacillus levels decrease inflammation and muscle atrophy markers in an acute leukemia mouse model. PLoS ONE 7(6): e37971.

56. Okada T, Fukuda S, Hase K, Nishiumi S, Izumi Y, et al. (2012) Microbiota-derived lactate accelerates colon epithelial cell turnover in starvation-refed mice. Nat Commun 4: 1654.

57. Pridmore RD, Berger B, Desiere F, Vilanova D, Barretto C, et al. (2005) The genome sequence of the probiotic intestinal bacterium Lactobacillus johnsonii NCC 533. Proc Natl Acad Sci USA 101(8): 25122517.

58. Sgouras DN, Panayotopoulou EG, Martinez-Gonzales B, Petraki K, Michopoulos S, et al. (2005) Lactobacillus johnsonii La1 attenuates Heliobacter pylori-associated gastritis and reduces levels of proinflammatory chemokines in C57BL/6 mice. Clin Diagn Lab Immunol 12(12): 1378-1386.

59. Ott SJ, Musfeldt M, Wenderoth DF, Hampe J, Brant O, et al. (2004) Reduction in diversity of the colonic mucosa associated bacterial microflora in patients with active inflammatory bowel disease. Gut 53(5): 685-693.

60. Manichanh C, Rigottier-Gois L, Bonnaud E, Gloux K, Pelletier E, et al. (2006) Reduced diversity of faecal microbiota in Crohn's disease revealed by a metagenomic approach. Gut 55(2): 205-211.

61. Nemoto H, Kataoka K, Ishikawa H, Ikata K, Arimochi H, et al. (2012) Reduced diversity and imbalance of fecal microbiota in patients with ulcerative colitis. Dig Dis Sci 57(11): 2955-2964.

62. Ahn JY, Sinha R, Pei ZH, Dominianni C, Wu J, et al. (2013) Human gut microbiome and risks of colorectal cancer. J Natl Cancer Inst 105(24): 1907-1911.

63. Mueller S, Saunier K, Hanisch C, Norin E, Alm L, et al. (2013) Differences in fecal microbiota in different European study populations in relation to age, gender, and country: a cross-sectional study. Appl Environ Microbiol 72(2): 1027-1033.

64. Rinne M, Kalliomaki M, Salminen S, Isolauri E (2006) Probiotic intervention in the first months of life: short term effects on gastrointestinal symptoms and long-term effects on gut microbiota. J Pediatr Gastroenterol Nutr 43(2): 200-205.

65. Wall R, Fitzerald G, Hussey S, Ryan T, Murphy B, et al. (2007) Genomic diversity of cultivable Lactobacillus populations residing in the neonatal and adult gastrointestinal tract. FEMS Microbiol Ecol 59(1): 127-137.

66. Costello EK, Lauber CL, Hamady M, Fierer N, Gordon JI, et al. (2009) Bacterial community variation in human body habitats across space and time. Science 326(5960): 1694-1697.
67. Almeida CC, Lorena SL, Pavan CR, Akasaka HM, Mesquita MA (2012) Beneficial effects of long-term consumption of a probiotic combination of Lactobacillus casei Shirota and Bifidobacterium breve Yakult may persist after suspension of therapy in lactose-intolerant patients. Nutr Clin Pract 27(2): 247-251.

68. Holmes E, Loo RL, Stamler J, Bictash M, Yap IK, et al. (2008) Human metabolic phenotype diversity and its association with diet and blood pressure. Nature 453(7193): 396-400.

69. Bäckhed F, Ding H, Wang T, Hooper LV, Koh GY, et al. (2004) The gut microbiota as an environmental factor that regulates fat storage. Proc Natl Acad Sci USA 101(44): 15718-15723.

70.Andrade S, Borges N (2009) Effect of fermented milk containing Lactobacillus acidophilus and Bifidobacterium longum on plasma lipids of women with normal or moderately elevated cholesterol. J Dairy Res 76(4): 467-74.

71. Cavallini DC, Bedani R, Bomdespacho LQ, Vendramini RC, Rossi E (2009) Effects of probiotic bacteria, isoflavones and simvastatin on lipid profile and atherosclerosis in cholesterol-fed rabbits: a randomized double-blind study. Lipids Health Dis 8: 1.

72.Gorenjak M, Gradišnik L, Trapečar M, Pistello M, Kosmus CP, et al. (2014) Improvement of lipid profile by probiotic/protective cultures: study in a non-carcinogenic small intestinal cell model. New Microbiol 37(1): 51-64.

73. Conde de la Rosa L, Schoemaker MH, Vrenken TE, Buist-Homan M, Havinga R et al. (2006) Superoxide anions and hydrogen peroxide induce hepatocyte death by different mechanisms: involvement of JNK and ERK MAP kinases. J Hepatol 44(5): 918-929.

74. Watson JL, Hill R, Yaffe PB, Greenshields A, Walsh M, et al. (2010) Curcumin causes superoxide anion production and p53-independent apoptosis in human colon cancer cells. Cancer Lett 297(1): 1-8.

75.Xie N, Cui Y, Yin YN, Zhao X, Yang JW, et al. (2011) Effects of two Lactobacillus strains on lipid metabolism amd intestinal microflora in rats fed a high cholesterol diet. BMC Complement Altern Med 11: 53.

76. Bull-Otterson L, Feng W, Kirpich I, Wang Y, Qin X, et al. (2013) Metagenomic analyses of alcohol induced pathogenic alterations in the intestinal microbiome and the effect of Lactobacillus rhamnosus GG. PloS ONE 8(1): e53028.

77. Hsieh FC, Lee CL, Chai CY, Chen WT, Lu YC, et al. (2013) Oral administration of Lactobacillus reuteri GMNL-263 improves insulin resistance and ameliorates hepatic steatosis in high fructose-fed rats. Nutr Metab (Lond) 10(1): 35.

78. Wang Y, Liu Y, Kirpich I, Ma Z, Wang C, Zhang M, Suttles J, McLain C, Feng W (2013) Lactobacillus rhamnosus GG reduces hepatic TNFa production and inflammation in chronic alcohol-induced liver injury. J Nutr Biochem 24(9): 1609-1615. 